\title{
CORONÉIS, FANTASMAS E SANTOS NA LITERATURA DE CICLO DO MODERNISMO
}

\section{Zama Caixeta Nascentes - e-mail: zcaixeta@cefetpr.br}

(Professor de Língua Portuguesa e Literatura Brasileira do CEFET-PR, unidade de Curitiba. Mestrando em Filosofia (UFPR). Psicólogo)

Resumo: analisaremos a peça teatral Zefa entre os homens mostrando como a trama estruturase a partir das idéias de crime e castigo, sendo religiosa a razão da queda do poder dos coronéis. Na seqüência, sobre os romances Bangüê e Usina, argumentaremos a favor da seguinte tese: a decadência dos proprietários de engenho e usina possui um motivo também religioso (castigo de Deus), e não apenas motivos econômicos (queda nos preços do açúcar, concorrência entre proprietários) ou psicológico (inaptidão para administração dos negócios agrários). Ao lado da tese da causação religiosa da decadência dos senhores do açúcar, comentaremos estes outros pontos comuns a essas três obras e a outras da nossa literatura: a existência de fantasmas e retratos nos antigos casarões e os elementos míticos-biblícos urdidores do enredo.

Palavras-chave: opulência, identificação, crime, decadência, castigo.

\section{Introdução}

Boa parte da literatura modernista toma como matéria de ficção o momento histórico do Brasil após a revolução de 1930 e os esforços do país de se modernizar. Necessário era ultrapassar uma economia essencialmente agrícola e dar espaços à indústria, repetindo-se etapas do capitalismo vividas na Inglaterra no século XVIII. Diante disso, escapa da aristocracia agrária, constituída desde as capitanias hereditárias, a multissecular hegemonia: casas grandes perdem o brilho e cobrem-se de pó e melão-de-são-caetano; fazendas despovoam-se e passam a habitá-las retratos, morcegos e fantasmas.

Poucos são os homens de botas e cavalos que conseguem trocá-los por sapatos e automóveis. Não conseguindo, são substituídos, restando-lhes viver da memória e da pretensa nobiliarquia herdada das caravelas de Martin Afonso de Souza ou extraída de Taques - como a nobreza de que nos dão notícias, em São Paulo, $A$ moratória e Os ossos do barão, Jorge Andrade, $O$ rei da vela e Marco Zero, Oswald de Andrade e, em Goiás, Dona Sá Donana, Bernardo Élis. Outra alternativa, além do agarrar-se às passadas grandezas, é o reengrandecerse compensatoriamente mediante uma transfiguração, possibilitada pelo recurso ao mítico e ao sobrenatural - casos, no Rio de Janeiro, do coronel Ponciano de O coronel e o lobisomem, romance de José Cândido de Carvalho, e, em Minas, do fazendeiro lô João-de-Barros-DinizRobertes de Tarantão meu patrão, conto de Guimarães Rosa.

Todavia, além de aparecer nessas obras como via de recuperação da grandeza perdida, 
a religião comparece em outras como causa da perda da grandeza, num processo de colagem de causas transcendentes (sacrilégio, castigo de Deus) às imanentes (alterações na ordem econômica ou gosto pelas letras e não pela terra). Averiguaremos essa fusão do transcendente e do imanente, ou seja, o entrelaçamento de razões econômicas com razões religiosas, as últimas presentes através da díade crime-castigo. Para tanto, lidaremos com o seguinte corpus literário: Bangüê e Usina, romances de José Lins do Rego, e Zefa entre os homens, peça teatral de Henrique Pongetti. De permeio, não resistindo a outros autores e obras, trabalharemos com eles para indicar mais pontos comuns à literatura de ciclo, embora agora nos interesse aquela fusão atuando na causação da decadência dos fazendeiros.

\section{1- "Eles abusam dos santos, exploram a fé do povo, mas um dia serão castigados":}

Desenvolveremos aqui a tese da religião como causa da perda da grandeza da aristocracia agrária, argumentando mediante a análise da peça teatral Zefa entre os homens, estreada no Teatro Nacional de Comédia do Rio de Janeiro em 30 de Outubro de 1962.

Transcorre no interior de Alagoas a ação, protagonizada por Zefa (criada pela atriz Nicete Bruno), ex-prostituta, "mulher bonita de meia-idade, fez vida na pensão da Noca, comprou um botequim" (p. 2). Em seu botequim entram e saem todos os personagens da trama. Contracenam com ela Bimbim e Lula (senhores de engenho), Pe. Gennaro (criado por Paulo Goulart), Inhaca e Tiquira (capangas a serviço do coronel Bimbim), Zé Pium (funcionário do botequim) e João Turco (paixão de Zefa).

Visando chuva e chuva de votos, os coronéis manipulam os santos de sua devoção, cujas imagens encontram-se nas capelas de seus engenhos: a de Nossa Senhora (coronel Lula) e a de São José (coronel Bimbim). Nessa manipulação teológico-política consiste o crime deles, conforme diálogo final do primeiro quadro do primeiro ato:

"ZÉ PIUM: - Eles abusam dos santos, exploram a fé do povo, mas um dia serão castigados.

"ZEFA: - (Como se seu cérebro se iluminasse de repente) - É mesmo!... Eu nunca tinha reparado nisso. Eles abusam dos santos e exploram a fé do povo. Misturam os santos com os touros. Apostaram, me fizeram entrar no jogo. Isso é sacrilégio, Zé, é sacrilégio (Pausa). Filhos da mãe!" (p. 7).

Crime e castigo são anunciados pelos "pequenos e humildes": é Zé quem profetiza a vinda do castigo. Empregado de botequim de "beira de estrada secundária do sertão" (p. 2), e mais, botequim de ex-prostituta, é humilde a sua condição[i]. Colocando na boca de Zé a 
profecia anunciadora do fio da trama (a trama é o tecer do castigo) e na de Zefa a denúncia dos crimes dos coronéis, Pongetti põe-nos em contato com o leit-motiv de sua peça: pelos humildes Deus castigará os poderosos.

Pedindo aos céus chuva, Pe. Gennaro também fará uma procissão com o seu Cristo Crucificado, nascendo daí, na trama, o clássico conflito entre poder eclesiástico e poder político. Se fossem concomitantes as santificadas carreatas[ii], o povo não saberia qual fora o santo milagroso[iii] e poderia creditá-lo ao santo do padre. Para resolver o impasse, propõe Bimbim uma manipulação, da qual os acusa Zé Pium no final do quadro primeiro, proposta formulada nestes termos: uma semana após a procissão do padre, Lula fará a dele e, na semana seguinte, Bimbim a sua. Entretanto, mela o pacto teológico-político entre os magnatas do açúcar: Bimbim ordena o roubo da santa de Lula a fim de impedir a procissão deste. Se abusar dos santos já era apontado por Zefa como sacrilégio, pior ainda o roubo da santa. Não fica para depois a intervenção dos céus e o início do castigo: os poderosos do açúcar precisam purgar seus pecados.

Roubada a santa, os capangas conduzem-na para o botequim. Começa a imagem a pesar, avisando aos dois que da casa de Zefa não queria passar, "INHACA - Assim que eu disse 'vamos esconder a santa na casa de Zefa', já pertinho daqui, a imagem desandou a crescer de peso, cresceu, cresceu, a cada passo nosso pesava mais, como se não quisesse ir mais adiante e entrar" (p. 10). Transforma-se em santuário (área santa) o botequim de uma "perdida", dupla qualificação do que a ortodoxia católica tem como profano (bebida e sexo extraprocriativo). Ficar na casa de uma ex-prostituta já indica a preferência dos céus pelos rebotalhos sociais, predileção a ser confirmada no desfecho da trama. No primeiro quadro, Zefa era comparada, por Tiquira, a Nossa Senhora, "TIQUIRA - Zefa, não é para você me fiar, juro pela alma de minha mãezinha, mas você é a mulher mais bonita que eu já vi. Parece uma Nossa Senhora" (p. 3). Agora a santa elege sua casa para hospedar-se. Por meio da taberneira, dos santos e do povo até então submisso, Lula e Bimbim serão destronados.

Voltando à idéia de intervenção, o peso da santa (mensagem da sua vontade de ficar no botequim) é o dedo de Deus na trama, pondo em marcha o castigo. Outra intervenção coincide com a segunda iluminação de Zefa, "estou vendo claro. Uma luz entrou no meu espírito" (p. 11). Bisiluminada, contraordena igual roubo do São José de Bimbim, "ZEFA - Vocês vão roubar o São José do Coronel Bimbim!" (idem), para espanto dos capangas, "INHACA - Heim? Roubar o São José do Coronel Bimbim? / TIQUIRA - Você não está regulando bem, Zefa!" (idem). Inúteis as resistências dos cabras, pois a iluminação assiste Zefa e ela não desiste, "ZEFA - Nunca regulei tão bem: vocês vão roubar agora mesmo o São José do Coronel Bimbim!" (idem). A terceira iluminação pode ser vista na forma miraculosa através da qual Inhaca e Tiquira executam o plano de Zefa:

"TIQUIRA - Foi outro milagre, Zé, isso é que foi! 
INHACA - Quando eu cheguei defronte do altar e disse: 'meu São Josézinho, eu vou levar você pra casa da Zefa', ele levantou os braços e foi vindo pro meu colo como criança quando está no colo de quem não gosta e vê o colo da mãe. Me puxava pra fora da casa, me puxava" (p. 14).

“...como criança quando está no colo de quem não gosta e vê o colo da mãe": reitera-se a idéia da predileção de Deus pelos humildes, já que os santos não se sentem bem na capela dos engenhos, "colo de quem não gosta", e preferem o botequim de Zefa, "o colo da mãe". Como Zefa já foi, no primeiro quadro da peça, comparada a Nossa Senhora, pode agora ser mãe de santos e acolhê-los em seu colo.

A ousadia de Zefa de ordenar o roubo, e que foi endossada pelo São José, não ficará impune. Os grandes coronéis revidarão: "Começou a turumbamba", noticia Tiquira no início do segundo ato. De fato, incendeiam-se os ódios dos coronéis, os dois aliançam-se, revistam a igreja à procura dos seus santos, "pareciam dois demônios com a peste na alma" (p. 15). Se já eram endemoninhados porquanto sacrílegos, agora mais ainda. Tiquira e Inhaca, armados, reúnem-se no botequim para proteger Zefa e os santos. Ao botequim chega, depois, o Pe. Gennaro, solicitado por Zefa para contar-Ihe o segredo do sumiço dos santos. Excetuando João Turco, estão em cena todos os personagens, uma vez que, após a entrada do Padre, adentram também os coronéis. É o ponto máximo da tensão da trama: defrontar-se-ão os poderes eclesiástico, político e popular. É grande o ódio dos dois coronéis por Zefa. Odeiam-na pela recusa em servir-Ihes bebidas e pela desconfiança de ser o botequim o esconderijo dos santos. Por desconfiarem, revistam a venda, invertendo os pecados de antes: se no final do quadro primeiro do primeiro ato Zefa os acusava de sacrílegos, agora Coronel Lula afirma: "Pe. Gennaro, nós até agora não revistamos esta casa porque achamos impossível alguém cometer o sacrilégio de esconder as nossas imagens debaixo da saia de uma prostitua" (p. 19). Resulta da busca o encontro de uma pedra da coroa da Nossa Senhora de Lula, prova, portanto, do "sacrilégio" da mulher e dos capangas.

Quando, diante da prova do crime, espera-se a execução não do castigo mas de mais crime por parte dos fortes coronéis, é que a situação inverte-se de vez: o povo abandona os coronéis e volta-se contra eles:

"CORONEL BIMBIM - (Que correu para a porta da rua, grita como um possesso). Sacrilégio! Os santos roubados estão na casa da Zefa! Ouviram? Na casa da Zefa! E Padre Gennaro está aqui dentro protegendo a vagabunda! Sacrilégio! Sacrilégio! Venham todos ver sacrilégio!

(Ouve-se forte tiroteio. Coronel Bimbim recua apavorado).

CORONEL LULA - Está ouvindo? Alguma coisa está acontecendo errada. A luta não devia ser aqui. O senhor não está estranhando? 
(Uma voz) - Coronel Bimbim, o povo vem vindo! O senhor fuja depressa, é muita gente, e bem armada!" (p. 20-21).

Se Zefa fora divinamente iluminada duas vezes, o povo o é agora: perceberam a manipulação dos coronéis com os santos - constatada por Zé Pium e Zefa desde o final do primeiro quadro. Cumpriu-se a profecia ameaçadora de Pe. Gennaro, "Mas o povo está cansado de ser enganado, não abusem mais tanto da sua resignação" (p. 19), como cumprida, em parte, está a de Zé Pium, "mas um dia serão castigados" (p. 7).

Acontecida a revolução político-teológica (mudança de posição dos eleitores, opção dos santos pelos pobres), resta a execução cabal do castigo: a derrocada final dos coronéis e o seu duplo assassinato. Antes disso, no entanto, numa espécie de confissão pública de crimes, e a subseqüente humilhação, Lula e Bimbim dialogam: este inaceita a desmoralização e a perda do seu prestígio - sentido já previsto na rubrica de entrada dos dois, "Estão visivelmente desmoralizados, mas querem manter outra aparência diante de Zefa" (p. 22) -, e aquele a tem como irreversível:

"CORONEL BIMBIM - Me acompanhe! Eu sou o Coronel Bimbim, e o senhor o Coronel Lula. Nós mandamos nisso tudo, temos de mandar. No último instante eles se arrependem da desobediência e se entregam. Venha comigo, vamos juntos gritar com eles. É preciso gritar com eles. Nós saímos sem gritar com eles. (Bebe outra talagada).

(Ruído de tirocínio à distância)

CORONEL LULA - Está ouvindo? Pela distância é na sua casa. Na minha devem ter passado antes. Gritar com quem, Coronel Bimbim? Com os nossos mortos ou com os nossos assassinos?" (p. 23-24)[iv]

Por fim, o castigo chega aos coronéis pelas suas próprias mãos: um mata o outro. Paradoxalmente, a vontade de poder deles se volta contra eles mesmos: não havendo mais a quem ordenar e matar, entreordenam-se devorantemente. Mortos os coronéis, Pongetti constrói o seguinte diálogo, com o qual ata as pontas do seu texto, retomando a denúncia do crime e a profecia do castigo lá do quadro primeiro do primeiro ato:

"ZÉ PIUM - (Espiando os mortos) - Eles se mataram sozinhos. É uma pena. Assim a morte nem parece castigo.

TIQUIRA - (olhando para os mortos) - Morte é sempre morte, Zé. Até que afinal os patrões tiveram de fazer o serviço com suas próprias mãos" (p. 24). 
A perda da autoridade e a morte dos dois possuem uma causação religiosa: é castigo. Não está em questão na peça a derrocada econômica dos senhores de engenho e em nenhum momento há referências aos seus apertos econômicos. Pelo contrário, indicações distribuídas ao longo dos dois atos dão conta das suas larguezas de cobres e cabras: "CORONEL LULA: Vocês vão ver depois a minha festa. A banda de música vem do Recife, é a do exército" (p. 4); "CORONEL BIMBIM: E lembrem-se, temos cabras novos e de confiança cercando a casa" ( $p$. 19). De natureza moral (não serem mais obedecidos) é a queda de Lula e Bimbim, "CORONEL LULA:- A essa hora a jagunçada já carregou as crianças e a mulher, já matou nossas esposas e nossos filhos, queimou nossas casas, mijou e escarrou nas cinzas e nos cadáveres" (p. 23), ou seja, não há mais quem dê ouvidos aos seus gritos (símbolos do seu poderio e elemento bastante presente nos coronéis de José Lins do Rego)[v]: "CORONEL LULA: - Gritar com quem, Coronel Bimbim? Com os nossos mortos ou com os nossos assassinos?" (p. 24). De grandeza só lhes resta a grossura do sangue, notada por Zé, por oposição ao "sangue de pouca tinta"[vi]

de Inhaca: "ZÉ PIUM - Como é grosso e vermelhão o sangue deles! Parece mingau. O do Inhaca, você viu, era ralinho, desbotado" (p. 25).

Exposto como a queda de Lula e Bimbim não tem a ver com embaraços econômicos, passemos ao romance Bangüê. Aproxima-se de Zefa entre os homens por ser castigado pelos poderes de Deus e dos santos a indiferença religiosa de Carlos; distancia-se por ser de cunho psicológico e econômico, e não religioso somente, o motivo da desautoridade do neto de Zé Paulino. A religião conjumina-se à psicologia e à economia e as três fornecem os fios com os quais se dá a tessitura da falência do protagonista e do engenho Santa Rosa.

\section{2- "Deus deixava o Santa Rosa num meio-dia de sol forte":}

Carlos fica, após a morte do avô Zé Paulino, com o engenho Santa Rosa. Fracassa na administração dos negócios por não ter jeito para a agricultura. Até aí uma razão psicológica: herdara do pai o gosto literário e por isso as habilidades agrárias do avô não se constituíram no ideal de eu de Carlos, "Eu era de outra raça, era neto de outro" (p. 452). Apesar desse fenômeno psicológico (identificação de Carlos ao pai), o romance é de caráter sociológico, posto Bangüêe e Usina, juntos, tratarem da substituição do modo feudal de produção, o engenho, pelo moderno, a usina, numa referência à industrialização do país, intensificada com a nova república. Mui engenhosamente, José Lins trabalha em seus romances do ciclo da cana-de-açúcar com estas duas categorias histórico-econômicas: apogeu-decadência, engenho-usina. Os romances Menino de Engenho e Bangüê tratam, respectivamente, do apogeu e da decadência do engenho[vii]. À decadência do Santa Rosa segue-se o início de uma nova etapa do ciclo do açúcar (a moderna usina), porquanto o desfecho de Bangüê seja a venda do engenho ao Dr. Juca, já com o propósito de ali construir uma usina. Usina tratará da implantação da usina, do 
seu apogeu e, por fim, da sua falência, vendida a outro usineiro, Dr. Luis, que a transforma em Santa Margarida. Num mesmo clã, o de José Paulino, o romancista faz incidir decadência e apogeu de duas formas de produção do açúcar: engenho e usina[viii]. É nisso que vemos sua engenhosidade.

Até aqui razão psicológica em Bangüê. Soma-se àquela razão psicológica a religiosa, marcada, como em Zefa entre os homens, pelo par crime e castigo. Trabalhando com esse aspecto, inseriremos também outra idéia importante neste estudo - a existência de fantasmas e assombrações habitando os engenhos decaídos -, dada a mistura, em Bangüê, de santos com fantasmas. Isso porque um dos crimes de Carlos, como em Zefa entre os homens, é o sacrilégio (mandou sair do engenho o antigo oratório do avô) e comete o crime precisamente porque os santos assombram-no por neles se fundir o fantasma do negro Nicolau. Leva-o a isso uma série de fatos, os quais nos conduzem de volta à categoria razão psicológica e nos permite introduzir a razão econômica. É sobre elas que passamos a discorrer.

"O santuário continuava a me amedrontar" (p. 465), afirma Carlos. Havendo aí um "continuava", necessário é retroceder no romance para localizar o começo do pavor infundido pelo oratório. Encontraremos então esta outra referência, "O quarto dos santos vivia fechado. Eu mesmo o fechara. Desde aquela noite de desespero, que me ficou um medo esquisito daquele quarto" (p. 436)[ix]. A qual noite refere-se o narrador? À da partida de Maria Alice, protagonista da parte II, hóspede do Santa Rosa a conselho médico para curar-se de "daquela moléstia, espécie de histerismo" (p. 328). Dupla é a cura: Maria Alice desacinzenta a vida de Carlos, "Onde estava a melancolia que punha cinza naqueles verdes, naqueles vermelhos do flamboyant? Andava cantando com o tempo" (p. 348) e Carlos, se não põe fim ao histerismo de Maria Alice - porque histeria não é moléstia e sim modo de o sujeito lidar com o desejo -, depois de várias transas com Maria Alice, devolve-a revigorada ao marido, "Maria Alice recebeuo no alpendre, fingindo satisfação. Estava alegre e abraçou o marido efusivamente" (p. 359). Representando cura para Carlos e sendo, em pleno engenho, uma interlocutora para o seu gosto pelas letras, a partida dela implicou a repetição das perdas primordiais já sofridas por ele: a da mãe (morte) e a da tia (casamento). De fato, Maria Alice porta os significantes da relação primordial de Carlos com o feminino: a sua mãe chamava-se Clarisse e a tia que substitui a mãe quando o menino foi para o engenho é Maria. Maria Alice reúne Maria e Clarisse, o que se revela no seu nome, posto ser ele uma condensação de Maria e Clarisse, este evocado homofonicamente em Alice. Logo, é difícil a Carlos metaforizar mais essa perda, "Maria Alice aleijara-me de uma vez" (p. 435). À partida de Maria Alice, dizíamos, refere-se o narrador quando menciona o início dos seus pavores diante do oratório, o que nos obriga a recuar mais ainda no romance. Na noite do dia da partida, Carlos fica totalmente transtornado, são atabalhoadas as suas andanças pela várzea e, à noite, em casa, tenta dormir. Não conseguindo, dirige-se ao santuário:

"E a agonia crescendo. Havia uma vela acesa no santuário. Noite de que santo era aquela? E a agonia crescendo. E se fosse rezar? Rezar o quê? 
O Anjo Gabriel de espada na mão, o outro com o carneiro nos braços. São Severino num caixão de defunto, e o Senhor Morto de sangue correndo das feridas. Por que não rezava? Sentia o cheiro do jasmineiro.

Maria Alice botava no seio aquela flor. Aquele pensamento danado não me deixava. Por que não rezava? Podia passar tudo aquilo com oração. $E$ fui andando para o oratório. Caí de joelhos. Vinham-me à cabeça, os peitos, as coxas, o corpo de Maria Alice. E nem um padre-nosso me saiu da boca. Não sabia nada. Fechei os olhos. Abri-os bem. A cara do Menino-Deus, tão pura. E só soube dizer, aos soluços, como qualquer pobre-diabo de engenho: - Nossa Senhora da Conceição, protegei-me" (p. 368).

Fundem-se aqui sexualidade e morte. Acresce-se à feição sinistra dos santos o momento de forte colorido emocional (perda de Maria Alice) vivido por Carlos ao ajoelhar-se diante do oratório e, então, entenderemos melhor porque, dois meses após a partida de Maria Alice, o pavor do santuário domina-o por inteiro, "Ficara com pavor do santuário. Quando via a porta aberta, assustava-me, fechando os olhos para não ver os santos" (p. 370). De consoladores os santos passam a desoladores. A "noite do desespero" mencionada à p. 436 é a da partida de Maria Alice e aqui o desespero é por tê-la perdido. O pavor é pavor de retornar às noites do tédio anteriores à chegada da mulher. Por processo metonímico - em que a flor do jasmineiro funciona como significante comum ao oratório e à mulher -, o pavor desloca-se para o santuário. Para esse objeto o desejo de Carlos se volta, levando-o a mesclar às orações "os peitos, as coxas, o corpo de Maria Alice", não sendo casual que sua oração invoque "Nossa Senhora da Conceição", mulher antes que santa.

Por razão psicológica entendemos o lugar privilegiado ocupado por Maria Alice e a impossibilidade de Carlos de substituí-la. A razão econômica consiste na decadência do engenho, provocada não mais pelos aspectos subjetivos de Carlos (não identificação ao avô, fixação em Maria Alice) e sim pela dupla concorrência sofrida pelo Santa Rosa após a morte de Zé Paulino: a do Capitão Marreira (ex-moleque do engenho, vai ocupando o vazio de poder deixado por Carlos, plantando canas, aumentando o gado e reformando casas dos empregados. No fim, Carlos tem de pagá-lo para sair das terras) e a do Dr. Luís (proprietário da Usina São Félix, cobiça as terras do Santa Rosa para expandir sua plantação). Nessa guerra surda (empreendida por confrontantes) pela expansão do latifúndio encontra-se a razão econômica da queda de Carlos. Não é em Bangüê e sim em Usina que a São Félix ficará com as terras do Santa Rosa, pois no desfecho de Bangüê o Dr. Juca, tio de Carlos, adquirirá as terras desgovernadas de Carlos, impedindo a passagem delas a estranhas mãos. $O$ evitado em Bangüê é o acontecido em Usina, acontecimento que possui razão religiosa (o sacrilégio do Dr. Juca) e econômica (queda no preço do açúcar, guerra latifundiarizante movida por Luis).

Retornemos aos fantasmas e à razão religiosa a operar em Bangüê.

Junta-se aos pavores do santuário um outro: o do fantasma da alma de Nicolau, feitor do engenho e morto em defesa de Carlos. Após a morte dele, Carlos é perseguido por um 
sentimento de culpa enorme, "pobre negro que se sacrificou por um senhor, indigno de seu sangue derramado" (p. 456). Se considerarmos que uma das imagens do oratório é a do "senhor Morto de sangue correndo das feridas" (p. 358), então entenderemos melhor porque, após a morte de Nicolau, engrandeceram-se os pavores de Carlos diante do santuário: o sacrifício de Cristo, representado na imagem, lembra a Carlos o de Nicolau. O próprio narrador encarrega-se de estabelecer a equivalência entre a partida de Alice e a morte de Nicolau, "Depois da morte de Nicolau, andei como naqueles dias da fuga de Maria Alice" (p. 462). Se é assim, aumenta o pavor pelo santuário, "O santuário continuava a me amedrontar" (p. 465), e o medo e o pavor, nascidos com a fuga da mulher, intensificam-se com a morte do negro:

\begin{abstract}
"Os meus sonos se cortavam com sustos. Sozinho no quarto, tremia como vara verde quando acordava com o escuro. Medo de Nicolau. Ouvia gemidos, e a cara dele, com os dentes brancos apodrecendo, com o seu sorriso bom, ficava ali perto, em cima de mim (...) Pelas barbas do senhor de engenho arrastavam os seus furtos. Poucos se incomodavam eles [agregados do engenho] com aquele resto de autoridade que tremia dentro da rede, com medo das sombras (...) Um senhor de engenho com medo de almas do outro mundo, com um cabra aos seus pés velando-lhe o sono! Só faltava correr das baratas, como mulher" (p. 462-464).
\end{abstract}

Encontramo-nos diante de um outro ponto recorrente na literatura de ciclo: decaído o engenho (moradores furtam madeira, avançam na plantação de mais e mais roçados e o senhor não toma nenhuma atitude), despovoa-se a casa-grande (Zé Paulino já está morto, Maria Alice há muito já foi embora, Maria Chica não adentra o quarto de Carlos para brincarem na rede, Carlos não recebe visita nem de parentes nem de figurões das circunvizinhanças) e ela povoase agora de sombras, visagens e fantasmas $[\mathrm{x}]$. Por medo dos santos do oratório, Carlos "prendia os santos no quarto porque, se visse aquela porta aberta e a cara das imagens, São Severino em caixão de defunto, seria o bastante para uma noite de desespero" (p. 465). O efeito da prevenção é o pior possível: as negras da cozinha comentam, " - É por isto que o diabo anda solto nesta casa" (p. 465), nomeando como "diabo solto" o objeto das próprias visagens de Carlos. Fantasmas e assombrações habitam o antigo engenho de Zé Paulino.

Enfim, o crime-sacrilégio de Carlos! Nesse cenário de total decadência econômica e tibieza moral, cometerá ele o dislate de mandar sair do engenho o santuário. Acompanhemos o despacho dos santos:

"A tia Maria soubera das minhas maluquices e me escreveu para mandar o santuário. Veio um carro de boi, coberto de esteira, para a viagem dos santos do velho Zé Paulino. Foi um rebuliço na casa. As negras entristeceram com a notícia (...) $E$ prepararam as imagens no carro, com os cuidados de quem estivesse conduzindo doentes. O velho santuário de jacarandá saía do Santa Rosa coberto de pano. E o carro 
se foi devagarinho. la gente atrás, contrita, acompanhando. Deus deixava o Santa Rosa num meio-dia de sol forte" (p. 465-466).

"Deus deixava o Santa Rosa": estamos diante do mesmo caso dos santos de Zefa entre os homens, qual seja, a mudança dos santos dos engenhos. A diferença é que em Bangüê os santos abandonam um engenho decaído[xi] e vão para outro, o da tia Maria (de cuja decadência nem grandeza temos notícias), enquanto que em Zefa saem de engenho com cem cabras e vão esconder-se "debaixo das saias de uma prostituta" (p. 19). A ausência dos santos de Zé Paulino não põe fim aos medos de Carlos, o que confirma nossa tese de serem os santos substitutos de outros objetos, esses, sim, fóbicos; longe de cessarem, agravam-se os temores de Carlos, chegando a querer a morte. No entanto, desejando-a, ocorrem-lhe os termos "morto, caixão de defunto", e com eles o objeto substituto do seu medo: o oratório com as imagens de "São Severino num caixão de defunto, e o Senhor Morto" (p. 368). Desiste de morrer e sente-se "como um menino perdido na multidão. Sem pai, sem mãe que lhe segurasse a mão débil” (p. 367)[xii].

Vimos o crime. Argumentemos agora porque o desfecho de Bangüê pode ser interpretado como castigo (agindo aí a razão religiosa), apesar da afirmação de Carlos nos capítulos finais, "De uma hora para outra era um homem rico" (p. 469). Seu castigo não será de ordem financeira - como o de Juca em Usina -, mas de outra, existencial, conforme veremos.

Fornece-nos a matriz da argumentação a favor da afirmação sobre a natureza do seu castigo a associação estabelecida pelo narrador entre Juca e demônio. Segundo a fala das negras, antes da saída dos santos o diabo andava solto na casa. Após a partida do oratório, dissemina-se pela várzea o boato da heresia de Carlos e do seu riobáldico-fáustico pacto, "tinha parte com o diabo". E realmente tinha, porquanto no penúltimo capítulo o diabo seja Juca e sendo ele tio de Carlos é claro que com ele o neto de Zé Paulino tem parte:

"Um dia porém, entrou-me a salvação dentro de casa. Não foi o diabo chegando de cavalo, com arreios de prata, e dente de ouro, belo como um príncipe a me oferecer tudo o que eu desejasse. Mas foi a cupidez humana, que é a mesma coisa. Tio Juca parou o seu automóvel na porta do Santa Rosa para conversar comigo. Viera comprar o meu engenho" (p. 468).

Juca é o diabo porque: 1) a cupidez humana é a mesma coisa que o diabo e se Juca é a cupidez então ele é o diabo; 2) a mefistofélica "salvação dentro de casa", inicialmente atribuída ao diabo, desloca-se depois para Juca, por ser ele quem retira Carlos das aperturas financeiras, salvando-o do mundo rural para onde ele nunca deveria ter ido; 3) o "cavalo com arreios de prata" equivale a "automóvel", moderno artigo de luxo por aquelas paragens e de largo trânsito e m Usina, simbolizando o poder dos usineiros. Aquele "não foi o diabo chegando a cavalo" pode ser perfeitamente substituído por este "chegando de automóvel" e teremos a versão 
tecnologizado do diabo e em Juca um exemplo bem sucedido de homem que conseguiu substituir cavalo por automóvel, conforme dizíamos na introdução; 4) o "dente de ouro", a designar na passagem acima o diabo, aplica-se a Juca nestas frases do cap. 5 da parte 3 , quando das contendas entre os herdeiros de Zé Paulino, "Tio Juca falou no gado, no dinheiro de ouro que o velho deixara" (p. 390), "Então Tio Juca voltou-se outra vez para o gado e para o ouro" (p. 391), "O Tio Juca voltava-se para o ouro. Alguém escondera o ouro do pai" (idem). O apego de Juca ao ouro já foi construído nessas passagens; logo, não é inverossímil que ele seja, como o diabo, "dente de ouro" (p. 468); 5) a salvação "dentro de casa" pode ser tomada em dois sentidos: dentro do espaço físico e dentro da linhagem fundada por Zé Paulino. Por esse segundo sentido, são os de casa (os familiares) que devem salvar do fracasso econômico os do mesmo clã, impedindo cair em mãos estranhas o legado de Zé Paulino, "um parente não passaria necessidade" (p. 469). Tal sentido para a expressão constitui o quinto argumento a favor da equivalência Juca-diabo, pois, nas demandas entre Carlos e Marreira, todos os parentes, os de "dentro da casa", se posicionaram a favor de Carlos, foram até o Santa Rosa a fim de encorajá-lo, exceto Juca: "Só o Tio Juca não apareceu, não me mandou recado. Sem dúvida que José Marreira contava com ele" (p. 423). Juca esperava desesperar por inteiro Carlos para, então, prestar-Ihe socorro, tentando-o com a proposta de comprar-Ihe o engenho.

Sendo Juca o diabo[xiii], o castigo de Carlos consiste em: 1) vir do diabo a sua salvação, paradoxo existencial pra lá de enlouquecedor!; 2) pesar-Ihe, no balanço da sua vida passada no engenho, a consciência da mais completa derrota, "Fracassara completamente", num último capítulo que bem poderia, à Brás Cubas, intitular-se "Das negativas": "Me degradara mesmo, fizera filhos em mulheres infelizes, dera em Pinheiro por causa de uma miséria, dormira com medo de cabras, de nada, de sombras" (p. 470); 3) perseguir-lhe os pavores acerca da morte, por ser o cemitério a última paisagem a enxergar da janela do trem, "O cemitério de São Miguel de Itaipu se mostrava do alto com suas cruzes velhas" (p. 471); 4) acompanhar-Ihe o remorso pela morte do feitor Nicolau, sentimento do qual quer livrar-se erigindo um túmulo, "Mandaria levantar um túmulo bonito para Nicolau (...) Um túmulo bonito para Nicolau". A quem nada conseguiu construir (família, romances[xiv], açúcares), só resta construir túmulos...

Passemos agora ao Usina para mostrar nele a díade crime e castigo e o entrelaçamento das razões econômicas às religiosas, do qual resultará a bancarrota da usina montada sobre os destroços do engenho Santa Rosa.

\section{3- "Veio porém a usina e não respeitou o oratório":}

Comecemos pelo crime-sacrilégio de Juca: a expulsão, da várzea para o alto da caatinga, do negro rezador Feliciano e dos seus santos. Afamado nas redondezas pelo poder de suas orações, competia o seu prestígio religioso (motivado, em parte, por ser Santa Luzia, que "fazia chover", uma das santas do oratório, assim como em Zefa entre os homens os santos todos. Ora, 
numa região assolada, não é de se estranhar ser poderosa a pessoa possuidora de um santo irrigador) com o do piedoso e pedófilo[xv] Manuel Pereira, igualmente preto e rezador. Lembranos essa rivalidade religiosa a competição entre o Cristo Crucificado do Pe. Gennaro, o São José do coronel Bimbim e a Nossa Senhora do coronel Lula de Zefa entre os homens. Necessitando de mais terras para expandir a plantação de cana[xvi], Juca não hesita em ocupar a terra santa da casa de Feliciano:

"Feliciano criara prestígio pelo seu santuário. As suas novenas criaram prestígio por toda a ribeira (...) E com isso o negro vivia. Não ia ao eito, plantava uns paus de roça (...) A casa do negro era a igreja do povo. E o pastor merecia todas as regalias. Veio porém a usina e não respeitou o oratório de Feliciano, que teve que deixar a casa de telhas da beira da estrada e conduzir os seus santos para o alto, acolher Santo Antônio e São Sebastião debaixo de folhas de catolé" (p. 780-781).

Ir para o alto (caatinga) foi o destino de todos os moradores das terras imediatas à usina (várzea), do qual não escaparam nem mesmo Feliciano e seus santos. A oposição caatinga/várzea é estruturante de todo o romance. Justifiquemo-nos. Essa oposição: 1) corresponde, sinonimicamente, a alto/baixo, lembrando-nos os termos teológicos céu/inferno, presentes, por exemplo, na oração católica do "Creio em Deus Pai", "subiu aos céus (...) desceu à mansão dos mortos". Esses sentidos estão presentes em Usina, uma vez que a obra é construída a partir da noção crime/castigo. Mescla-se à conotação teológica a econômica: a várzea é o céu tanto para o usineiro quanto para os trabalhadores, dada a fecundidade da terra, enquanto que a caatinga é o inferno para os trabalhadores, por causa da escassez de água, e o céu para o usineiro, pois lá exila quem se opõe à sua ambição por mais terra[xvii]. Sendo assim, cria-se uma ambigüidade interessantíssima em torno dos termos: o "alto", que na religião é o céu, no romance é o inferno (paradoxalmente, o lugar para onde vão os santos de Feliciano), pois lá a terra não produz o de comer e o povo passa fome; o "baixo", que na religião é o inferno, no romance é o céu, se pensado em termos econômicos (condições propícias para a agricultura), mas é também o inferno, se tomado em termos teológicos (pois não há mais santos na várzea, como não houve mais no Santa Rosa - situado também na mesma várzea - após a partida do oratório de Zé Paulino narrada em Bangüê); 2) funda outra, pobreza/riqueza: na caatinga o povo não tem onde plantar os seus roçados, aumentando sua miséria e trazendo a fome, por oposição à abastança da várzea, sede da usina e da casa-grande do usineiro; 3) mede o poderio de Juca: quanto maior, mais gente expulsa para a caatinga; quando desandam seus negócios, andam os do povo, pois os antigos moradores começam a retornar à várzea, onde podem plantar seus roçados, criar os seus xerimbabos e tomar da água doce do Vertente e não mais da salobra sobra do Paraíba, o rio esgoto[xviii] da usina; 4) aplica-se à competição surda entre Juca e Luís (proprietário da Usina São Félix, vizinha à Bom Jesus): Luís "viera da caatinga para a várzea" (p. 776) enquanto Juca sempre fora da várzea. Mais uma vez, caatinga é o lugar da pobreza (pois de lá saiu Luís para tentar a vida na várzea), por oposição à várzea, 
propícia à cultura da cana e, portanto, ao enriquecimento, como é o caso de Luís[xix]; 5) vive-a o próprio Juca no desfecho do romance: tendo perdido as terras da usina, estando incapacitado de caminhar e fugindo de uma enchente que cobre as antigas instalações da Bom Jesus, Juca sobe da várzea para a caatinga, onde se refugia, percorrendo o caminho outrora feito pelo povo.

"Conduzir os santos para o alto" representou para Feliciano uma queda da qual não conseguiu mais se reerguer - como, em Zefa, manipular os santos foi queda para Bimbim e Lula e, em Bangüê, mandar embora os santos intensificou os sobressaltos de Carlos que se viu mais paralisado ainda na administração do engenho. Prenuncia-se o crepúsculo dos santos de Feliciano na passagem atrás transcrita: deixam de ser cobertos por telhas e passam a sê-lo por folhas de catolé, ou seja, os santos decaem "socialmente". Se em Zefa entre os homens os santos preferiam a pobreza do botequim ao luxo da capela do engenho, em Usina não podemos falar o mesmo dos santos de Feliciano. O negro cessa o culto e não temos notícias se os santos acomodaram-se às folhas de catolé. Por fim, da narrativa da partida dos santos, talvez seja esta frase a melhor para dar conta do tom sacrílego da ação de Juca: "não respeitou o oratório de Feliciano". Diferente seria se lêssemos "não respeitou Feliciano" ou "não respeitou a casa de Feliciano". Houve um desrespeito ao oratório, como em Zefa entre os homens, quando os santos eram colocados, na fala dos coronéis, junto com os bois e eram instrumentos de manobra eleitoral. Tão alta aleivosia ao alto exige das alturas castigo à altura.

Vimos que em Zefa entre os homens havia duplo sacrilégio. Num primeiro momento, sob a ótica de Zefa, o que os coronéis faziam com os santos; num segundo, sob a ótica dos coronéis, o que Zefa, Inhaca, Tiquira e o padre fizeram (esconder os santos no botequim). Bangüê não nomeava como sacrílega a ação de Carlos de mandar para o engenho da tia Maria o oratório, embora fosse tachado de herético e pactoso com o Cujo. A nomeação é nossa e não do narrador. Aqui em Usina não demorará o julgamento, "O povo viu a coisa como um sacrilégio" (p. 781), para, logo em seguida, ser profetizado o castigo: "Aquilo um dia se acabaria e então os seus santos teriam de descer outra vez. Deus mandaria. Deus não se esquecia do povo. Deus castigava os grandes" (p. 781). Nisso, notamos outra simetria com Zefa. Nas duas obras, ao invés de uma revolução socialista, temos uma teofania; no lugar da virulência política, o discurso literário adquire contornos religiosos[xx], como se a alteração da ordem social[xxi] só fosse possível pelas mãos de Deus[xxii].

Suspendamos por ora o castigo, pois não parou aí o crime. Perdido seu santuário, Feliciano deu para andar pela várzea resmungando e praguejando. Um dos lugares onde o negro sempre parava era no barracão da usina, fornecedor de mantimentos para os operários da fábrica._Ernesto, encarregado do barracão, não suportava muito o rezador, " - Este negro é um boca de praga" (p. 781). Descontente com as reformas de Juca - uma delas a canalização do rio Vertente para abastecer a usina -, Feliciano agoura ainda mais. Num momento de impaciência, Ernesto surra o negro: "E quando Feliciano foi se chegando mais para perto, seu Ernesto pulou o balcão e passou-lhe o metro nas costas. O negro velho caiu urrando no chão. Seu Ernesto bufava" (p. 787). Não se bate em cego nem em doido. Embora não tenha sido Juca o agressor, a arbitrariedade é tributada a ele também, porquanto executada por um empregado de sua 
confiança. Espancar um negro leso é crime aos olhos dos antigos moradores do engenho e exige castigo: "A negra Generosa pediu a Deus que castigasse Seu Ernesto na hora da morte" (p. 787). Corre a notícia da surra, "Até D. Dondon, na Paraíba, soube e escreveu sentida ao marido" (p. 795). Juca repreende os desmandos de Ernesto. Todavia, se formos ao final de Usina, perceberemos ter, de fato, recaído sobre Juca a praga endereçada a Ernesto pela negra Generosa: Juca cai adoentado de um mal na espinha e perde os seus movimentos, assim como caíra o negro Feliciano na porta do barracão.

Ensimesma-se mais e mais Feliciano, "Falava só, atendendo a interlocutores invisíveis, gente de um mundo que só existia para ele" (p. 816). Não permitindo ao povo cultuar seus santos, de crente Feliciano passa a ter fama de pactante com o Não-sei-que-diga - mesma acusação sofrida por Carlos em Bangüê. Se antes suas pragas poderiam atrair castigos sobre os da várzea, agora é o seu suposto endemoninhamento o imã para desgraças, "O Dr. Juca devia tomar uma providência, porque podia cair um castigo sobre o povo, uma febre, uma desgraça maior" (p. 817). Exalta-se mais ainda a imaginação do povo quando "Uma noite correu uma notícia: a casa de Feliciano estava pegando fogo. $O$ fogo ardia nas palhas secas e o negro estava lá dentro" (p. 819): o fogo passa a ser tomado como "castigo do céu" e a interpretação popular não se faz esperar, "O diabo não havia podido com Deus" (idem).

Leva Juca a outro sacrilégio o fim trágico de Feliciano. O local do incêndio transforma-se em ponto de peregrinação e não se espalham as cinzas e sim o boato de possuírem as cinzas propriedades miraculosas. $O$ incêndio fora o fogo santo de Deus porque queimara o negro endiabrado e poupara os santos, não achados entre as cinzas. Capangas da usina tentam dissolver os romeiros (por uma razão econômica: o povo deixa de ir ao trabalho para fazer peregrinação) mas são escorraçados pelos crentes[xxiii]. Convoca Juca reforço policial para a tarefa. Exitosa é a operação; todavia, nesse êxito está o outro sacrilégio de Juca (o primeiro foi expulsar os santos para a caatinga): "Em cima das cinzas de Feliciano correu sangue de inocentes" (p. 823). No caso da surra, foi Generosa, negra do engenho, quem clamou por castigo; no do massacre do Alto da Areia (local do fogo santo), foi a velha Nenen - crítica mordaz das modernidades[xxiv] de Juca - quem sentenciou e profetizou o castigo: "Onde já se vira uma coisa daquela, atirar no povo, fazer mortes como se fosse em bando de arribação? Deus castigaria" (p. 836).

E veio o castigo à industriosa insolência sacrílega de Juca. A frase "Em cima das cinzas de Feliciano correu sangue de inocentes" fecha o capítulo 15 da parte II de Usina e o seguinte inicia-se com esta, "Naquele ano a Bom Jesus não moeu, como se esperava" (p. 823). É difícil ver só justaposição ou casualidade aí: a nosso ver, a relação de contigüidade estabelece a de causalidade. Quando todos - familiares e engenheiros - esperavam alta produtividade da usina, frustram-se. O açúcar, puro cristal o esperado, vem "um cristal escuro e úmido que nem se comparava com o da São Félix" (p. 823). O sangue dos inocentes tinge o cristal da Bom Jesus! Vingado está Feliciano, vingada está a soberba empreendedora de Juca, que carreou para a usina a água do Vertente, deixando ao povo a barrenta água do Paraíba onde a usina despejava seus detritos. Retornam os detritos agora, escurecendo o que deveria ser açúcar- 
cristal[xxv]. Não obstante fosse exígua a moagem e impuro o açúcar, o preço era bom: "Apesar de tudo, o preço compensava de tantos contratempos. Um saco de cristal por $60 \$ 000$, dava para tudo e ainda sobrava" (p. 825).

Grande está sendo o castigo; todavia, apenas começa. Ambicionando aumentar capacidade de produção, Juca empreende reformas na usina, substituindo as peças iniciais, compradas de outra usina: "E fizeram a usina Bom Jesus, com as ferragens adquiridas de uma outra, que se desfizera de ferro velho para aumentar de capacidade" (p. 715). Para tanto, necessitara de mais capital e do maquinismo fabricado por estrangeiros[Xxvi]. Viera-Ihe da casa Vergara o capital, por empréstimo, com o aval dos parentes todos, inclusive o sogro. Tamanho investimento só seria rentável se o preço do açúcar se mantivesse. Não foi isso o que ocorreu.

Cair violentamente os preços foi a continuidade e o agravamento do castigo. Purgado o açúcar escuro das primeiras parcas safras, veio a desgraça maior. A queda de Feliciano em frente ao barracão de Ernesto é experimentada por Juca agora: a queda do preço do açúcar e a subseqüente queda econômica e social de Juca, com dívidas e cortes em seus fornecimentos:

"A grande crise do açúcar pegou a Bom Jesus de jeito. Dois anos de moagem boa, de cristal de primeira. E o saco de açúcar por $20 \$ 000$. Os compromissos enormes, os cálculos feitos na alta. As despesas com safras gigantes e a Bom Jesus sem recursos próprios, sem Banco, sem crédito para agüentar. Quem visse o Dr. Juca de agora não o reconheceria" (p. 852).

É tão grande a crise que Clarinda, fiel amante de Juca (não recebia homens desde o usineiro), muda da pensão francesa para a pensão Peixe-Boi (o nome já diz tudo do nível inferior que é a nova casa) e passa a ter outros homens, levando alguns homens a mofarem, "Não havia amante fiel com açúcar de 20\$000" (p. 878), assim como "com açúcar de $20 \$ 000$ o saco, o melão-de-são-caetano subiria pelas chaminés de usinas" (p. 853) - o mesmo sãocaetano que medra em tantas outras obras da literatura de ciclo, constituindo-se a planta em tropos literário modernista, assim como verdes relvas alcatifantes constituíram-se em imagem recorrente nas paisagens construídas pela ufanista literatura romântica. Cair o preço do açúcar é um fenômeno a obedecer à lógica do capital internacional[xxvii]; portanto, é uma causa estritamente econômica. A essa razão imanente (como dizíamos na introdução) para a degringolada dos negócios de Juca junta-se a transcendente: trata-se de um castigo dos céus às atitudes sacrílegas do usineiro. Feliciano, Generosa, tia Nenen profetizaram-no. A heresia de Juca já sofrera golpes desde que sua esposa, D. Dondon, depois da baixa produtividade da usina após as reformas, retorna à casa-grande (agora dividida com o químico americano) e com ela os seus santos e o seu oratório. É o retorno do expulsado. A presença de D. Dondon encoraja os trabalhadores, antes escorraçados das proximidades da usina, a aproximarem. Inicia-se o processo da descida da caatinga para a várzea, ou seja, o retorno do exílio - outro tema bíblico na urdidura da narrativa. A decadência de Juca implica a ascensão do povo, "Para o povo pobre da Bom Jesus há dois anos que a vida vinha melhorando" (p. 871). Piorando mais ainda a situação, Juca adoece, "Sentia-se doente, uma fraqueza nas pernas" (p. 872), um bem 
sucedido exemplo de deslizamento semântico construído por José Lins: quando alguém fracassa financeiramente, o uso lingüístico dispõe de "não anda/vai bem das pernas", expressão aqui migrada para outro contexto (doença no corpo) e que conserva, no entanto, a idéia de fracasso econômico.

Culmina o castigo de Juca numa paralisia quase completa, a ponto de precisar ser carregado. Sua queda é muito maior que a de Feliciano. O desfecho do romance é trágico e mítico: uma enchente[xxviii] inunda a usina e Juca tem que subir para a caatinga, lugar para onde expulsara o povo e, em especial Feliciano. Se este profetizara "os seus santos teriam que descer outra vez" (p. 781), cumpriu-se duas vezes seu anúncio: uma quando, não os seus santos e sim os de $D$. Dondon, desceram e foram habitar a própria casa-grande e não simplesmente "a casa de telhas da beira da estrada" (p. 780); outra quando o próprio Juca teve que subir para a caatinga, humilhado, entrevado, fracassado economicamente, retirante de uma enchente. Igualam-se Feliciano e Juca e aplainam-se as desigualdades sociais: se um incêndio destrói a casa de palha de Feliciano na caatinga, uma enchente afoga a casa-grande, como Feliciano afogara os seus santos. Incêndio e enchente: elementos bíblicos e míticos com os quais José Lins tece o crime e o castigo do usineiro da Bom Jesus, assim como em Zefa entre os homens chuva (que seria obtida através da manipulação dos santos) e fogo de revólver compunham o pecado e a expiação dos coronéis Bimbim e Lula.

\section{CONCLUSÃO}

"Sim, podia [o casamento] ser também um modo de restituir à vida a unidade que perdera, com a troca do meio e da fortuna". Com esse pensamento de Rubião, expresso no cap. 79 de Quincas Borba, queremos arrematar nosso trabalho. Isso porque muito da prosa modernista já se encontra na machadiana. De fato, a problemática de Rubião, "perda da unidade", tem uma razão econômica, "a troca do meio e da fortuna", isto é, ter saído da província para a corte (como Ponciano e outros personagens analisados aqui, que deixam a roça para viver na cidade) ou ter mudado rapidamente de situação financeira (caso de muitos aristocratas da terra vistos ao longo deste trabalho).

"Unidade perdida" vimos nos coronéis Lula, Bimbim, Ponciano, Lula e Afonso; nos descendentes de Zé Paulino e Frederico, que Ihes sucederam na administração do Santa Rosa e do São Martinho, e nas últimas gerações dos Chaveiros. Perdem-se a unidade de "bens e sangue" (conflito entre gerações, falência dos negócios, enfraquecimento das novas gerações) e a unidade política (o poder sai das mãos da aristocracia agrária). Não bastando essas perdas, há esta: a unidade psíquica estilhaça-se porque os personagens se constituíram a partir de signos (a nobreza do nome, os gritos de comando fincados no poder da propriedade agrária, a obediência de empregados e familiares), dessignificados agora na nova ordem social. Em Quincas Borba, Rubião quis casar-se para reaver a unidade perdida; em Bangüê, o perdido 
Carlos quis matar-se e não o fez porque o salvou o diabo comprando-lhe o engenho, devolvendo a Carlos a vida da cidade, parte do seu "meio"; em Usina, Juca não conseguiu resgatar o perdido, desejando, como Carlos, a morte quando, no desfecho, se viu diante do deslustre social. Não se casando, Rubião substituiu a unidade perdida mediante um delírio de grandeza. Provinciano de Barbacena, Rubião perdeu-se porque não aprendeu, na corte, a "educação da sala", assim como Lula, Carlos e Eduardo, moços da cidade, não aprenderam a educação da sela, fragmentando-se tanto quanto Rubião. O delírio dele faz série com as atitudes de Ponciano e lô João-de-Barros-Diniz-Robertes: os três buscam, e conseguem, reaver suas grandezas perdidas, os dois últimos fazendo-o através do mítico.

No plano do mítico podemos colocar ainda a subversão vista em Zefa entre os homens e Usina. Querendo ser revolucionárias ou, no mínimo, sociológicas, as obras aqui analisadas foram-no só através do recurso ao teológico, eludindo a revolução socialista, como se nem mesmo na ficção fosse possível a revolução socialista. A derrota do mais forte pelo mais fraco só ocorreu por uma mediação sobrenatural, manifesta sob a forma de castigo. O Deus surdo dos poemas Vozes d'África e O navio negreiro, Castro Alves, parece ter em Zefa e Usina ouvido o grito enviado a Ele pelos brasileiros, escravos do capital internacional desde que "Colombo abriu a porta de teus mares".

\section{REFERÊNCIAS BIBLIOGRÁFICAS}

ADONIAS FILHO. As velhas. Rio: Bertrand Brasil, 1993, $2^{\mathrm{a}} \mathrm{ed}$.

ALVES, Castro. Poesias completas. Rio: Ediouro, 1995, 18르 ed.

ANDRADE, Oswald. O rei da vela. São Paulo: Globo, 1994, 4ª ed.

ARANHA, Graça. Canaã. Rio: Nova Fronteira, 1982.

ASSIS, Machado de. Quincas Borba. In. Ficção completa, v. I. Rio: Nova Aguilar, 1997.

. A semana. In: Ficção completa, v. III. Rio: Nova Aguilar, 1997.

BRAGA, Rubem. Fim de semana na fazenda. In: 200 crônicas escolhidas. Rio: Record, 1998, $13^{\mathrm{a}}$ ed.

CARVALHO, José Candido. Olha para o céu, Frederico. Rio: José Olympio/Civilização Brasileira/Três, 1974.

O coronel e o lobisomem. Rio: José Olympio, 1985, 37ª ed.

DRUMMOND DE ANDRADE. Poesia e prosa, volume único. Rio: Nova Aguilar, 1992, 8ª ed.

ÉLIS, Bernardo. Dona Sá Donana. In: Veranico de Janeiro. Rio: José Olympio, 1987, 6ª ed. 
FONSECA, Rubem. O cobrador. São Paulo: Companhia das Letras, 1989, 3르 ed.

LACAN, Jacques. As estruturas freudianas do espírito. In: O seminário, livro 5: as formações do inconsciente. Rio: Jorge Zahar, 1999.

LISPECTOR, Clarice. Feliz aniversário. In: Laços de família. Rio: Francisco Alves, 1993, 25ª ed.

MELO NETO, João Cabral. Obra completa. Rio: Nova Aguilar, 1994.

MUNIZ, Lauro César. O santo milagroso. Revista do Teatro. Rio: SBAT, 1967.

NETTO, Coelho. Tapera. In: Sertão. Porto: Lelo \& Irmão, s/a.

PONGETTI, Henrique. Zefa entre os homens. Revista do Teatro. Rio: SBAT, 1963.

QUEIROZ, Rachel. A beata Maria do Egito. Rio: José Olympio, 1989. In: Obra reunida, v. 5.

RAMOS, Graciliano. Angústia. São Paulo: Círculo do Livro, 1987.

REGO, José Lins do. Ficção completa, vv. I e II. Rio: Nova Aguilar, 1987.

ROSA, Guimarães. Fiç̧ão completa, vv. I e II. Rio: Nova Aguilar, 1995.

VARELA, Fagundes. Poemas. Erechim: Edelbra, s/a

[i] Lembra-nos o Timpim Vinte e Um de Duelo, conto de Guimarães Rosa: enclenque e destituído de poder (por ser o vigésimo primeiro filho e ter levado surra de todos os irmãos mais velhos), é Timpim quem derrota o até então invicto Turíbio Todo.

[ii] Carreata santa, mas não eleitoreira, realiza o protagonista de Tarantão meu patrão, num processo de transfiguração religiosa que o retira da decadência física, "Lá se ia, se fugia, o meu esmarte Patrão, solerte se levantando da cama, fazendo das dele, velozmente, o artimanhoso. Nem parecesse senhor de tanta idade, já sem o escasso juízo na cabeça, e aprazado de moribundo para daí a dias desses, ou horas ou semanas" (p. 501), e econômica, por ser antiga a fazenda e mal conservada a escada, "desço em pulos passos esta velha escada de pau, duma droga, desta antiqüíssima fazenda, ah..." (idem), escadona a ser vista, em Goiás, no casarão dos Chaveiros de Bernardo Élis. Outro elemento a confirmar essa perda de prestígio é este excerto. "O velho me pespunha o azul daqueles seus grandes olhos, ainda de muito mando delirados", delírio encontrado também nos coronéis Ponciano, Lula e na Sá Donana dos Chaveiros. Delirase para reaver a importância tida um dia.

E seria para delirar mesmo o caso do protagonista: "O que era se ser um descendente de sumas grandezas e riquezas - u m lô João-de-Barros-Diniz-Robertes! - encostado, em maluca velhice, para ali, pelos muitos parentes, que não queriam seus incômodos e desmandos na cidade. $\mathrm{E}$ eu, por precisado e pobre, tendo de agüentar o restante, já se vê, nesta desentendida caceteação que me coisa e assusta, passo vergonhas" (p. 502). Diferente dos 
descendentes de Zé Paulino, permanecidos a maior parte $n$ a roça, com opulência ou decadência, os de João-de-Barros-Diniz-Robertes foram para a cidade e lá não queriam saber do ancestral. Pois bem, é para lá que ele está indo! Promete matar o sobrinho médico, " - 'Ei, vamos, direto, pegar o Magrinho, com ele hoje eu acabo!' - bramou, que queria se vingar. 0 Magrinho sendo o doutor, o sobrinho-neto dele, que dera injeções e a lavagem intestinal. 'Mato! Mato, tudo!' - esporeou, e mais bravo" (p. 502).

É nessa viagem com destino à cidade que se dá o que estamos nomeando de "transfiguração", ou seja, o velho vai agregando em torno de si uma comitiva que lhe devolve as "sumas grandezas" e, aos poucos, o texto transforma-o não mais em alguém vingativo ou diabólico, conforme ele se via no começo, " “ - Eu 'tou solto, então sou o demônio!' " (p. 502), e simnuma autêntica figura alegórica_de Cristo a caminho de Jerusalém._Essa figura alegórica já fora trabalhada por Guimarães_no protagonista de_A hora e a vez de Augusto Matraga: o autor coloca-nos Matraga convertendo-se, penitenciando-se e, depois, saindo pelo mundo, montado num burrinho (Cristo e lô Robertes), certo de que "todos têm a sua hora e a minha vai chegar" (mulinha e protagonista com feições messiânicas lemos no desfecho de $O$ coronel e 0 lobisomem também: "Lá vai o Coronel Ponciano de Azeredo Furtado em sua mulinha de desencantar lobisomem. Vai para a guerra do Demônio, que o coronel não tem medo de nada", p. 303, confirmando assim nossa tese de ser a transfiguração religiosa uma forma de reaver as grandezas perdidas). O primeiro a juntar-se ao patrãoe_ao seu servidor (narrador) é um "ajudante-de-criminoso": " - Venha comigo, vosmicê! Lhe proponho justo e bom foro, se com o sinal de meu servidor" (p. 503); o segundo, uma mulher pobre, a quem é dado o cavalo do lô João, "Nisto, o visto: a que ia com feixinho de lenha, e com a escarrapachada criança, de lado, a mulher, pobrepérrima (...) o meu patrão se apeou, e a fez montar em seu cavalo. Cuja rédea ele veio, galante, a pé, puxando" (idem). Chegam a um povoado, onde o filho da mulher, "por ver a mãe tão rainha tratada" (idem), quis agradecer largamente, o que foi recusado por lô , antes ordenando, " " - Arranja cavalo e vem, sob minhas ordens, para grande vingança, e com 0 demônio' "(p. 503-504). Estranha vingança!_,uma vez que,_o que o conto põe diante dos nossos olhos, é um personagem que até agora só praticou "boas ações".

O sentido bíblico da carreata de lô João ganha mais nitidez quando chega ao arraial do Breberê. justo um dia de "Festa de Santo". Foguetes e sinos para o santo o são agora para lô João, " - Tão me saudando' " (p. 504). Nessa transfiguração, readquire as grandezas perdidas. Uma das suas ações no arraial é, de fato, de santo, "E sacou o que teria em algibeiras. E tinha. Vazou pelo fundo. Era dinheiro, muitíssimas moedas, o que no chão ele jogava" (p. 504). realizando a partilha, não dos pães mas sim do dinheiro, repetindo uma cena que em Fogo Morto é protagonizada pelo cangaceiro Antônio Silvino (distribuir dinheiro dos ricos aos pobres). Ao sair do arraial "Os sinos em toada tocavam" (p. 505). Para ele, claro, e não mais (ou não só) pelos santos.

Na travessia de um córrego (água: elemento carregado de conotações bíblico-míticas), a carreata incorpora mais um traço sagrado, a penitência: " “ - os cavalos bebem. A gente, não. A gente não tem sede!' Por áspera moderação, penitência de ferozes" (idem). Diante desse patrão agora, é outro o olhar de Vagalume, personagem narrador: "O Patrão, pescoço comprido. o grande gogó, respeitável. O rei guerreiro. Posso fartar de suar; mas aquilo tinha para grandezas" (idem. Destaques nossos). Foram resgatadas as grandezas perdidas.

Prossegue a viagem até a cidade e à casa do sobrinho neto chega justo no dia "de um batizado: o de filha do Magrinho, doutor!" (p. 506). Atam-se as pontas das diferentes gerações: 
batiza-se a mais nova da família e chega o mais velho. O olhar de surpresa da família sobre ele confirma, mais uma vez, que ele é outro, "A família, à reunida, se assombrava gravemente, de ver o Velho rompendo - em formas de mal-ressuscitados" (p. 506). Mal-ressuscitado, sim, mas outro, capaz de fazer uso da palavra outra vez, rompendo o silêncio que a família impusera-lhe fixando-o na roça: "O Velho, fogoso, falava, falava e falava. Diz-se que, o que falou, eram baboseiras, nada idéias já dissolvidas. O Velho só se crescia" (p. 507). Temos aqui a contrapartida do poder das palavras. Isso porque, readquiridas as grandezas, lô pôde falar, ou seja, poder implica falar, a contraparte do que tantas vezes lemos em Guimarães: falar implica poder.

Damos por justificada aqui nossa afirmação de haver em Tarantã o meu patrão um "reengrandecer-se compensatoriamente mediante uma transfiguração religiosa" e de ser santa sua carreata da fazenda até a cidade onde moram os parentes, e não eleitoreira.

[iii] Coronéis e santos figuram também na peça O santo milagroso (1963), de Lauro César Muniz. Disputando o poder local ("pequena cidade do interior paulista", não nomeada), encontram-se o Padre José e o Pastor Camilo, disputa metaforizada na pescaria da abertura da peça e na partida de xadrez jogada na sacristia da matriz. Tira disso proveito o Coronel Francisco: converte-se ao protestantismo para obter os votos dos protestantes, reconverte-se ao catolicismo depois de propalado o milagre do santo, promete casar o seu filho ora no templo protestante ora na matriz, chantageia o padre e o pastor com a possibilidade de doar-lhes um casarão para sediar os projetos sociais deles. Como Bimbim e Lula, Francisco manipula a religião com fins eleitoreiros (maquinação facilitada por ser Francisco o nome do santo milagroso). A diferença, com relação a Zefa entre os homens, é que em $O$ santo milagroso as próprias autoridades religiosas são as primeiras a agirem maquiavelicamente, num flagrante desrespeito à firme fé dos fiéis. Divididos nas suas ambições por hegemonia espiritual sobre a população e enredados sempre mais na confusão gerada pelo equívoco do santo milagroso, José e Camilo pouco podem objetar às manobras políticas do Coronel Francisco. O povo comparece apenas como rebanho fácil de ser conduzido, não havendo, em nenhum momento, o esboço de uma reviravolta política, como a que veremos a seguir em Zefa entre os homens.

[iv] Convém destacar desse diálogo o contraste entre os coronéis, posto haver, em outras obras, outros oligarcas da terra desconhecendo a derrota e, quixotescamente, gritam com mortos ou fantasmas. Pensamos nestes:

1 - no Coronel Ponciano, de $O$ coronel e o lobisomem, José Cândido Carvalho: sua fortuna, feita nos currais, é perdida na especulação com compra e venda do açúcar (referência a três atividades econômicas - pecuária, monocultura canavieira e comércio -, razão suficiente para pôr o romance, bem como Olha para o céu, Frederico, do mesmo autor, no rol da literatura de ciclo, no caso, o ciclo da cana-de-açúcar da região de Campos no Rio de Janeiro). Fracassado como especulador (por existirem as gentes dos bancos do Rio a controlarem tudo, constatação do caráter circulante do capital), Ponciano quis reassumir a fazenda do Sobradinho - abandonada a outros olhos que não o do dono. Ao regressar à fazenda, encontra-a ruída e roída. Inaceitando a derrocada financeira, o coronel quer fazer valer os seus "berros de curral" (símbolos de seu poder) de outrora e, quixotescamente, investe contra supostos soldados e cobradores de impostos que estão chegando às suas terras. Delira. Embaraçando-se nas vassourinhas (praga equivalente do melão-de-são-caetano que cobre as desgraças dos engenhos caídos), cai. A queda é pra lá de simbólica, posto ser metáfora não só da perda da fortuna como também da perda da realidade (delírio) nas últimas cenas do romance. Completa a 
formação delirante o combate ao fantasma, feito através de um cavalo descido dos céus: o próprio coronel, antes perseguidor de lobisomens, sereias e uraraus, transfigura-se agora em um ente fantasmagórico e desliza sobre nuvens, montado num cavalo que "devia ser prenda de São Jorge, que sempre soube apreciar o valor de um estribo e a força de uma rédea" (p. 303) revelando-se aqui, mais uma vez, a presença de santos e coronéis, assunto muito do nosso agrado neste trabalho. Transfigura-se Ponciano tanto quanto lô-João-Robertes, do conto de Guimarães, e Honório Silveira, do conto Tapera, de Coelho Neto, (Honório torna-se lenda: "Os sertanejos falam desse velho como falam do curupira e da yara das águas correntes", p. 119). Necessário é ressalvar que em questão em Tapera está um drama amoroso e não uma derrocada financeira. Retornaremos ao conto na seqüência;

2- no Quincas de Barros, de Olha para o céu, Frederico: Como Ponciano, transforma-se também em visagem o senhor de engenho Quincas de Barros, após a falência: "Diziam que Quincas de Barros andava aluado. Um meladeiro encontrou o dono da São José sem leme, de olhar vermelho em jeito de pitanga. Pensou até que fosse uma penitência, uma assombração da tarde" (p. 78), parecido com o mestre Amaro, o lobisomem de Fogo Morto, com as devidas diferenças porque Zé Amaro não resiste ao desaparecimento do ofício de seleiro (substituído pelas selas de produção industrial) e não à falência de engenho, posto ser ele agregado (embora rejeite, enfaticamente, o epíteto de camumbembe) e não dono de engenho;

3- no Coronel Lula, de Fogo Morto, José Lins do Rego: fracassado na administração do engenho (por uma razão psicológica semelhante à de Carlos: Lula é moço da cidade e sofreu com a morte do seu pai, morto em combates políticos nos idos de 1848. Da morte do pai, Lula nunca se recuperou, como Carlos não elaborou a da mãe), o coronel fracassa também na educação da filha Nenen, destinada a substituir, no universo afetivo de Lula, a mãe e as irmãs dele e a casar com gente graúda. Sem provimentos para a família e sem os afetos da filha depois da proibição do namoro, agarra-se Lula às rezas para não sucumbir de vez e fantasia-se com grandezas passadas, reservando a si distinções sociais (não se misturar ao povo do Pilar, passear na traquitana do cabriolé) cuja razão de ser é o dinheiro do dono de engenho, coisa escasseada no Santa Fé desde a morte do Capitão Tomás. Como Ponciano, vê inimigos onde não há, um deles uma mula despelada abrigada da chuva no telhado da casa e tomada por Lula como o namorado da filha em ação de roubo da donzela. Contra o suposto raptor, Lula dispara tiros. Aproxima-o mais uma vez de Ponciano as quedas: tentando defender a casa do ataque do cangaceiro Capitão Silvino, é Lula quem sofre de um ataque de nervos: cai e baba. Outra cena em que cai é quando afugenta um comprador do Santa Fé;

4- no avô de Luís Silva, de Angústia, Graciliano Ramos: "Depois da abolição, já sem forças, ainda conservava os modos de patriarca" (p.117). Ressaltem-se as diferenças de Angústia frente aos outros romances aqui mencionados: não se centra na decadência agrária do avô ou do pai, como se pode deduzir desta afirmação do narrador, "Conheci Trajano decadente, excedendo-se na pinga e já sem prestígio para armar cabroeira e ameaçar a cadeia da vila" ( $p$. 118), ou seja, o narrador conheceu o avô já decaído, não sendo, pois, testemunha da falência. Central no romance é o esforço do descendente de Trajano, Luís Silva, de sobreviver na cidade, "como a cidade me afastara dos meus avôs" (p. 84), através do seu ingresso no serviço público, tornando um "parafuso insignificante na máquina do Estado" (p. 95);

5- na matriarca dos Chaveiros, de Dona Sá Donana, Bernardo Élis: queda também nessa matriarca da colonização e do povoamento de Goiás. Desrespeitando a ordem de Donana, Diomede começa a cavar o porão à cata de tesouros enterrados (indicação de falência 
econômica: só se desenterram tesouros de porões quando as burras da família estão vazias). A proibição da escavação se ancora na superstição de o desenterro dos tesouros implicar morte dos donos da casa (e, no desfecho, Donana morre: confirmou-se a superstição ou foi mera casualidade?). Acordando com o barulho das escavações, Donana decide ir até o porão fazer valer sua autoridade e pôr cobro aos trabalhos: "Estavam muito enganados e Dondom que arredasse que ela ia descer aquelas escadas que ela não descia fazia bem uns vinte anos. la descer e ia correr com o Diomede a pau e a cacete para ele largar de atrevimento, ora essa! então cavar o porão do sobrado sem sua licença, sem seu consentimento. Tinha graça!" (p. 129). Com dificuldades, desce as escadas de madeira do casarão. O fim da escada já lhe aparece como sepultura (o que, do ponto de vista da feitura da narrativa, é a preparação da morte iminente da personagem), "Cá de cima, à luz mortiça da lamparina, até parecia que a escada não tinha fim, que se metia pelo chão adentro, numa cova escura como deveria ser uma sepultura" (idem). O texto prepara ainda mais a morte da matriarca com a sufocação, "Foi neste ponto que Donana parou, sentiu a sufocação com uma intensidade tão grande que não resistiu: deixou-se cair sentada no degrau da escadona, e no sufragante a própria lamparina lhe escapou das mãos e foi rolando escada abaixo, o pavio largado um pouco abaixo pisca-piscando nas vascas da morte" (idem). Caem Donana, "deixou-se cair sentada no degrau da escadona", e a lamparina; desgarra-se da lamparina o pavio, como antes desgarrara-se o fôlego de Donana; apaga-se a chama do pavio: há aqui todo um rosário de símbolos do fim próximo de Sá Donana metaforizando (o rolar escadas abaixo na perda do prestígio social) a decadência em que, já há anos, se encontrava a dinastia dos Chaveiros, cuja dignidade feudal remontava a Portugal e a Espanha: "Tia de seu Evangelista, o marido dela descendia diretamente do coronel Ignácio de Morais Chaveiro, Guarda-mor das minas de ouro que deram origem ao lugar, e de que fora ele o descobridor e explorador. Ligava-se, por essa forma, aos Bandeirantes, aos velhos troncos paulistas catalogados por Pedro Taques, com ramificações em Portugal e Espanha, numa corrente infindável que Dona Sá Donana recitava de cor, cheia de intimação, balançando a cabeça adonde uns brincos de ouro lembravam passada opulência e muito orgulho relutando por sobreviver" (p. 102). Não sobreviveu o orgulho: extinguiu-se com o apagar do fôlego de Sá Donana. Todos esses elementos permitem inserir o conto de Bernardo Élis na literatura de ciclo do modernismo - no caso, os diferentes ciclos econômicos da colonização do estado de Goiás.

Insistindo ainda mais nesse fim de dinastia, o contista mantém na infância o filho mais novo de Donana, Dondon, incapaz de qualquer iniciativa. De fato, "Chaveiro tá dano em água de barrela" (p. 116). Essa tese da degeneração aparece em outros clãs, como o do capitão Tomás (Fogo Morto); o do coronel Zé Paulino, "Eu não podia com o seu cacete. O sangue não estava no meu" (Bangüê p. 452), e "Sangue do seu povo estava degenerado. Os antigos não deixavam rastro, tinham-se ido para sempre" (Usina, p. 836); o do Frederico, "E eu impotente contra essa onda de desmandos que vinha com pés de paina. Em todo lugar eu via Frederico, os olhos de pitanga" (Olha para o céu, Frederico, p. 124); o de Trajano Pereira de Aquino Cavalcante e Silva, "Lembrava-me disso [a obediência dos capangas ao avô e do poder de morte do avô via tocaia] e apalpava com desgosto os meus muques reduzidos" (p. 118), o mesmo "reduzido" já usado no início do romance para nomear o encurtamento do nome do pai e simbolizar a degeneração das novas gerações. Salvadas as especificidades da prosa de Clarice Lispector, encontramos a mesma tese no clã da matriarca de Feliz aniversário, "Oh o desprezo pela vida que falhava. Como?! como tendo sido tão forte pudera dar à luz aqueles seres opacos, com braços moles e rostos ansiosos? Ela, a forte, que casara em hora e tempo devidos com um bom homem a quem, obediente e independente, respeitara; a quem respeitara e que Ihe fizera filhos e the pagara os partos. $O$ tronco fora bom. Mas dera em aqueles azedos $\mathrm{e}$ 
infelizes frutos, sem capacidade sequer para uma boa alegria. Como pudera ela dar à luz aqueles seres risonhos fracos, sem austeridade?" (Laços de família, p. 78).

Dos aristocratas, restam retratos a espiar o fracasso das novas gerações. E retratos é o que não falta nessas obras. Exceção feita ao conto de Clarice, há-os em: Bangüê, "Fui até a sala de visita e olhei o meu avô, no quadro da parede. O olhar bom, a cara sem malícia alguma, o homem que em oitenta anos gritou por ali, mandou, fez e desfez por sua própria conta (...) O neto era um fraco" (p. 430); Olha para o céu, Frederico, "Precisou que Frederico viesse para endireitar o retrato daqueles barbadões que dormiam dependurados nos pregos das paredes" (p. 95), o mesmo Frederico cujo retrato será retirado da parede pelo sobrinho Eduardo, herdeiro do engenho São Martinho, "E quando a noite chegou, longe das vistas de alguns agregados, retirei o retrato de Frederico da sala de visitas. E mandei pedir a tio Nabuco, em carta cheia de efes e erres, que mandasse uns desenhos do brasão de nossa gente" (p. 103); Dona Sá Donana, "O casarão de Donana, o único sobrado da cidade, com janelas em arco, vidraças de malcacheta, estava arruinado, o beiral cindido, o soalho apodrecido, com os baldrames e barrotes roídos de cupim (...) Sobre tais destroços, a sala forrada de papel, as cadeiras de circunstâncias, os velhos quadros dos avoengos estampando semblantes sérios e maus" (p. 107); Fim de semana na fazenda, crônica de Rubem Braga de setembro de 1957, "São fazendas dos fins do século passado, não mais. seus donos ainda estão lá; já não se balançam, é verdade, nas cadeiras austríacas da varanda; nem ouvem a partida desse bando de maritacas que se muda para o morro do outro lado da várzea. / Ou talvez ouçam, quem sabe. Mas estão hirtos dentro de suas molduras, nas paredes da sala. Assim, rígidos, pintados a óleo, eles parecem reprovar nossos uísques e nossas conversas" (p. 208); Retrato de família, poema de "A rosa do povo" de Drummond, "Este retrato de família / está um tanto empoeirado. / já não se vê no rosto do pai / quanto dinheiro ele ganhou. // Nas mãos dos tios não se percebem / as viagens que ambos fizeram. / A avó ficou lisa, amarela, / sem memórias da monarquia" (p. 143).

[v] Bem como na matriarca de Bernardo Élis. Acostumada a gritar nos tempos de grandeza, conserva o hábito mesmo na decadência, passando a gritar, compensatoriamente, em sonhos, "Em breve Donana roncava no quarto, e dava gritos brigando com as negras, defendendo seus ouros que os outros queriam tomar (...) Pelas brigas, pelos gritos, Dondom sabia que a velha tinha caído no sono" (p. 130). Lembra-nos Donana o Capitão Vitorino de Fogo Morto, gritador também, embora com meninos motejadores ou com mulheres, indicação suficiente de que já não tem mais a quem gritar.

[vi] "Somos muitos Severinos / iguais em tudo na vida: (...) / e iguais também porque o sangue / que usamos tem pouca tinta" (p. 172). Inhaca é também Severino, morrendo "de emboscada antes do vinte", por uma "ave bala voando desocupada". (MELO NETO, João Cabral. Obra poética. 172-173).

[vii] Em Fogo Morto temos, no mesmo romance, o apogeu de Zé Paulino (basta lembrar que é ele quem põe fim ao assalto do cangaceiro Antônio Silvino ao engenho Santa Fé e intercede junto aos políticos da Paraíba para a soltura de Vitorino) e a decadência do coronel Lula (tanto assim que sua esposa sustenta a casa com a venda de ovos!). Além dessa díade, a obra dá-nos notícias da início de novos engenhos, o que acontece mediante a expropriação das terras dos pequenos agricultores (caso de Quincas Napoleão).

[viii] Diferente é o fenômeno em Olha para o céu, Frederico, de José Candido Carvalho: durante a vida de Frederico, o engenho sempre esteve em alta; após a morte, o São Martinho passa ao 
sobrinho Eduardo, em cujas mãos ocorre a transformação do engenho em usina, chegando essa última depois à falência pelas mesmas razões da Bom Jesus de Usina. Consiste nisto a diferença: a etapa da decadência do engenho foi saltada.

[ix] A prática de manter fechado o quarto dos santos remonta à infância de Carlos no engenho, sendo, portanto, um hábito de Zé Paulino, consoante narrado em Menino de engenho: "Mas o quarto dos santos vivia fechado. Não havia no engenho o gosto diário da oração. Talvez que o exemplo do meu avô, justo e bom como ele era, mas indiferente às práticas religiosas, arrastasse os seus a esses afrouxamentos de devoções" (p. 80). O novo consiste no medo e nos pavores, razões pelas quais Carlos fecha o oratório agora, e nas conseqüências do seu gesto.

\section{[x] Assombrações povoam também:}

1- a casa grande de Frederico, de Olha para o céu Frederico: o São Martinho, depois da falência de Eduardo como usineiro, é descrito nestes termos: "O casarão dos Sá Meneses, enterrado na noite, era de meter medo. Em todo lugar eu via Frederico, os olhos de pitanga de meu tio. Não metia rifle de vigia no lado de fora só para não dar parte de fraco. Certa noite sonhei que estava sendo esganado. Acordei com um nó na garganta, ensopado da cabeça aos pés, como se tivesse caído num banhado. Pequei ódio pelas corujas que cortavam mortalha em cima do telhado" (p. 124-5). Experiencia Eduardo o mesmo pavor de Carlos no Santa Rosa. A diferença é que Carlos não consegue escrever romances, enquanto Eduardo nisso encontra a saída para o seu desespero, "Só tinha um desafogo. Cair nas resmas de papel" (p. 125). No avançar da falência, o próprio Eduardo transforma-se em fantasma, "O ano virou o rabo e eu enterrado na São Martinho. Inchei, deixei crescer a barba. Perambulava pelos corredores do casarão como um penitente do outro mundo" (p. 127), lembrando-nos, de imediato, Ponciano e Lula.

2- o casarão dos Chaveiros, de Dona Sá Donana: "Para a mulher de capitão Benedito quem estava aparecendo no sobrado era uma irmã de Boiota, bonita demais da conta, que se atirou no poço da casa com uma criancinha no peito, tudo paixao pelo velho marido de Dona Sá Donana. isso faz muitos e muitos anos. Para Sinhaninha era uma tia do marido de Donana, que se perdeu com um moleque da casa, e que a família, desde então, passou a ter trancada no porão com a desculpa de que era louca varrida" (p. 127). Numa sociedade patriarcal, para a transgressão das interdições sociais (escrava apaixonar-se pelo patrão, filha de branco apaixonar-se por "moleque da casa") há punição_até depois da morte, como se não bastassem as de vida (suicidar-se, ser tachada de louca e trancafiada num porão), consistindo essa punição em não ter descanso nem na eternidade. Outra referência a assombrações é esta. "Para afugentar morcegos e assombrações, tinha [Donana] sobre a mesa uma lamparina de azeite, de chama mortiça mas firme" (p. 130).

3- o casarão do Coronel Afonso, de Canaã: O romance de Graça Aranha trabalha com a segunda colonização (chegada do imigrante europeu) e com a tese racista segundo a qual a decadência do Brasil devia-se à miscigenação. Sendo essa a razão do fracasso da civilização brasileira, a alternativa seria o incentivo da imigração européia, a chamada segunda colonização. O fantasma a que nos referimos é o vulto do Coronel Afonso, visto por Milkau no capítulo primeiro, quando o alemão desce do Queimado para o Cachoeiro. Durante seu trajeto. Milkau vê as ruínas da civilização brasileira, tentada construir a partir da miscigenação: "Milkau cumprimentou, tirando cortesmente o chapéu; o homem lá no alto correspondeu, erguendo indolente o sombreiro de palha. O dono da fazenda, de pés nus, calça de zuarte, camisa de chita sem goma, parecia, com a barca branca, muito velho, atestando na alvura da tez a pureza da 
geração. A fisionomia era triste, como se ele tivesse consciência de que sobre si recaía o peso do descalabro da raça e da família; o olhar, turvo, apagado para os aspectos da vida como o de um idiota; o esgotamento das suas faculdades, das emoções e sensações era completo e o reduzira a uma atitude miseranda de autômato. Mas, ainda assim, ele representava a figura humana, a mesma vida superior envolta na queda das coisas, arrastada na ruína geral" (p. 31). Embora represente a "pureza da geração", o Coronel é caracterizado como decaído, "pés nus, fisionomia triste", alusão à ruína da civilização agrária fundada no trabalho escravo - conforme descrição do casarão feita anteriormente no romance. Curiosamente, a seqüência de Canaã não trabalhará nem com o tema da decadência da civilização escravocrata nem com o do nascimento da civilização do "trabalho livre" - expectativa inicialmente criada quando vemos Milkau chegar a Cachoeiro e empreender negócios com Roberto Schultz. Isso nos leva a acreditar nas influências simbolistas presentes no romance e que esmaecem o caráter de "ensaio sociológico" da narrativa - caráter que se debuxa nos primeiros capítulos.

[xi] Apesar disso, não se pode, marxistamente, afirmar ser Deus patriarcal e agrário, ou seja, decaídos os engenhos, nem mesmo Deus quer lá ficar. Isso porque, no conjunto da obra de Zé Lins, há casos de engenhos decaídos em que a religião é a âncora para os falidos. Assim, no engenho Santa Fé, Fogo Morto, Lula e D. Amélia apegam-se mais à religião à medida que ruem casa e negócios; na usina Bom Jesus, Usina, D. Dondon, após a degringolada dos negócios de Juca, retorna à usina - depois de longa temporada morando na cidade - e com ela os santos, intensificando suas rezas.

[xii] Remete-nos às suas vivências infantis de orfandade narradas em Menino de Engenho: "A morte de minha mãe me encheu a vida inteira de uma melancolia desesperada. Por que teria sido com ela tão injusto o destino, injusto com uma criatura em que tudo era tão puro? Esta força arbitrária do destino ia fazer de mim um menino meio cético, meio atormentado de visões ruins" (p. 56).

[xiii] Em O rei da vela há também essa associação entre dinheiro e diabo, pois João, irmão de Heloísa, a noiva de Abelardo I, reconhece o Rei da Vela como o diabo porque Abelardo é possuidor de capitais:

"D. POLOCA - No meu tempo, as meninas eram recatadas. lam às novenas. Rezavam o terço. Hoje é o diabo quem manda!

JOÃO - O diabo é o homem mais encantador do mundo. O Homem da Vela... de Heloísa.

HELOÍSA - O Rei da Vela. - Me dá um cigarro, tia.

JOAO - Não quero saber. A vela dele é que nos salvou" (p. 67).

[xiv] Confessa Carlos no capítulo de abertura de Bangüê o seu contato, na faculdade de Direito, com a "literatura que se fazia naquele tempo" (p. 292), numa referência à literatura de ciclo dentro da qual se enquadra o romance Bangüê: "Um senhor de engenho era um motivo literário de primeira ordem" (idem). Não nos deteremos aqui em discutir o fato curioso de Carlos construir e não construir ao mesmo tempo os romances em que "viam-se esses homens toscos [senhores de engenhos] como verdadeiros aristocratas" (idem) porque já o abordamos em outro estudo nosso sobre os personagens-autores em José Lins do Rego, Érico Veríssimo e Jorge de Andrade. 
Discutiremos, sim, a semelhança entre Carlos e Eduardo, de Olha para o céu, Frederico, no tangente a projetos literários.

Eduardo também se mete a romancista dos ancestrais, enaltecendo todos, "Que ficasse sabendo o ilustre articulista que minha casa de dois andares tinha, em suas recordações, muitos outros tipos de nobreza, barões de sangue limpo, um Pedra Lisa que deixou fama, que foi íntimo de $\mathrm{dD}$. Pedro. Arrotei grandeza por tudo que foi vírgula. Falei até em cartas que o imperador escreveu a meu bisavô" (p. 11). Essas louvaminhas aos "toscos homens" são rejeitadas por Carlos (ele, de volta ao Santa Rosa, se dá conta de que a realidade do povo do engenho seré bem diferente daaquit que se-encontrada na literatura) e por Eduardo, "O certo mesmo é apresentar meu tio como era, como viveu no São Martinho" (p. 20-21). Outro aspecto em comum é que ambos escrevem, de fato, os seus romances, posto Olha para o céu, Frederico (1939) ser narado em primeira pessoa tanto quanto Menino de engenho, Doidinho e Bangüê. A diferença é dar-nos notícia Eduardo, no interior da sua própria narrativa, do processo de construção do romance, mediante capítulos iniciais recheados de debate estético à São Bernardo (1934). Graciliano Ramos - notícias e debates não divulgados por Carlos.

[xv] O prestígio de Manuel Pereira está narrado na parte I de Usina, centrada no retorno do moleque Ricardo ao Santa Rosa após seu exílio em Recife e Fernando de Noronha. Na verdade, a parte I é a continuação de $O$ moleque Ricardo, 1936, (Usina é de 1937), cujo desfecho era a partida de Ricardo para Fernando de Noronha. Para o Recife fugira pensando sair do cativeiro do engenho. Outro maior cativeiro o esperava, o do trabalho assalariado e, por

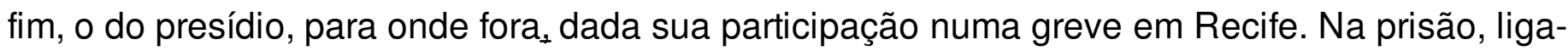
s e, homossexualmente, a Manuel, cozinheiro, de cujos carinhos Ricardo terá boas lembrançasque este the dispensava. $\Theta \underline{A}$ s easos de-ligações homossexuais fno presídio levamno à lembrança de caso parecido no engenho: "No engenho havia no entanto um velho dado àquela história. Era o negro Pereira que tirava esmola para os santos. Chamavam de Tio Mane Pereira e ele sempre tinha um moleque fornido, morando em sua casa. Diziam que ele gastava o dinheiro de Nossa Senhora do Rosário com os amigos (...) Gostava de viver com homens" (p. 683).

[xvi] A usina automatiza toda a produção: o transporte da cana dos partidos para o local da moagem (antes feito por carros de bois, agora é feito por trens), a colocação da cana nas moendas (manual no engenho, mecânico - por esteiras automáticas - na usina) e a forçamotora das moendas (bois e burros são substituídos pela força da água - alusão direta à revolução industrial inglesa). Tal automatização aumenta muitíssimo a capacidade de produção e expandir a área plantada é preciso. Isso implica expulsão do povo da várzea para a caatinga e proibição do plantio dos roçados para subsistência dos agregados: toda a terra é para produzir cana para alimentar a usina - como na Inglaterra do XVIII toda a terra era para criar ovinos, cuja lã se constituía na matéria-prima da indústria têxtil.

Há também em $O$ rei da vela o tema da extinção da pequena propriedade, motivado pela latifundiarização ou pela aplicação do capital especulativo ao campo (ou seja, comprar terra é, em determinados momentos, um bom negócio; ainda que o neoproprietário nada de terras entenda, é "legítimo" desalojar quem tem as raízes na terra, uma vez que o capital não pode ficar ocioso. A substituição dos donos da terra aparece nesta fala de Abelardo: "ABELARDO I - Estamos de fato num ponto crítico em que podem predominar, aparentemente e em número, as pequenas lavouras. Mas nunca como potência financeira. Dentro do capitalismo, a pequena propriedade seguirá o destino da ação isolada nas sociedades anônimas. $O$ 
possuidor de uma é um mito econômico. Senhora minha noiva, a concentração do capital é um fenômeno que eu apalpo com as minhas mãos. Sob a lei da concorrência, os fortes comerão sempre os fracos. Desse modo é que desde já os latifúndios paulistas se reconstituem sob novos proprietários" (p. 55).

[xvii] "O que o mar sim ensina ao canavial: / o avançar em linha rasteira de onda; / o espraiar-se minucioso, de líquido, / alagando cova a cova onde se alonga". MELO NETO, João Cabral. Obra completa, p. 340.

[xviii] E não o rio menino de O rio de João Cabral de Melo Neto: "Desde tudo me lembro, / lembro-me bem de que baixava / entre terras de sede / que das margens me vigiavam. / Rio menino, eu temia / aquela grande sede de palha, / grande sede sem fundo / que águas meninas cobiçavam" (p. 119).

[xix] Em O coronel e o lobisomem há uma oposição de espaço físico que se reveste de sentido sociológico. Coronel Ponciano é da fazenda, onde fez fortuna com pastos, currais e bois. Essa a fortuna a ser empregada na especulação com o açúcar, causa da sua falência econômica. Já Baltasar é da cidade e, como engenheiro, vai para a fazenda de Ponciano, onde aumenta seu pecúlio. Aproveitando-se do auge das especulações do coronel, empreende reformas devoradoras de altas somas de dinheiro, tudo indicando ficar em seus bolsos mesmo os cobres. O campo é, portanto, para os dois, o lugar de engordar os bolsos, como a várzea em Usina. A cidade, só por um tempo, foi "mina" para Ponciano, revelando-se depois o caráter perverso da especulação financeira urbana.

[xx] Alinha-se às obras aqui interpretadas a peça teatral de Rachel de Queiroz, $A$ beata Maria do Egito. A rejeição do novo governador do Ceará por parte de Pe. Cícero leva-o a organizar os romeiros para fazer frente à força policial do estado que vem intimá-los à rendição e à aceitação do curso "normal" da política. Maria, a Beata, põe o seu carisma (é tida como santa) a serviço da causa dos rebelistas, sendo por isso presa. Na prisão, opera-se o "milagre": à semelhança da Judith bíblica, ela se deixa seduzir (seduz?) pelo tenente (o Holofernes da narrativa bíblica). Com isso, inverte-se todo o jogo de forças do início da trama: o Coronel Chico Lopes (quem açula a prisão de Maria), à semelhança de Bimbim e Lula de Zefa entre os homens, tem que sair correndo da delegacia para não ser morto pelos revoltosos; o Cabo Lucas, submisso ao delegado, rebela-se contra ele quando o delegado quer tomar Maria como mulher e não como santa e acaba matando-o com a faca (símbolo da sua renúncia ao posto de soldado - um soldado usa arma de fogo - e da sua adesão à causa dos rebelistas); o tenente, depois de ter tentado uma delirante defesa da delegacia, é morto pelo Cabo; a Beata, aprisionada no início da peça, sai triunfante da prisão - com portas abrindo-se de um modo a lembrar-nos a maneira pela qual o apóstolo Pedro é libertado da prisão. Como nas demais obras, também em $A$ beata Maria do Egito a vitória dos oprimidos sobre os opressores (simbolizados no Coronel e no tenentedelegado) só é possível por meio da intervenção do sobrenatural e não pela organização e pela estratégia político-militar dos pequenos. A fala final da beata na peça, "Glória a Deus!", reitera que é Deus quem conduz os destinos de um povo (no caso os rebelistas) e que a soberba de Chico Lopes foi castigada (teve de sair correndo da delegacia e, lá fora, os revoltosos tomam-lhe o revólver. É, pois, desmoralizado tanto quanto o foram Bimbim e Lula).

[xxi] Se não alteração dessa ordem social, pelo menos uma grande vingança social é empreendida por Luís Silva, de Angústia, Graciliano Ramos, posto o seu ato de assassinar Julião Tavares (caracterizado no romance como pertencente à classe burguesa, dadas as 
referências constantes à casa comercial do pai, cujo nome, Julião Tavares \& Cia, substitui nalguns momentos o do próprio Julião) se revestir do sentido de cobrança de uma dívida social, nos moldes do que faz Rubem Fonseca no conto $O$ cobrador. Acompanhemos a construção disso na narrativa:

1- Luís afirma, "Agora Quitéria [escrava do avô Trajano] estava morta. E os filhos dela e os das outras pretas que, depois de 88 , foram viver em ranchos de palha, nas ribanceiras do Ipanema, começavam a desacatar os descendentes dos antigos senhores. Muitos andavam nos grupos de salteadores que assolam o nordeste, queimando propriedades, violando moças brancas, enforcando os homens ricos nos ramos das árvores" (p. 118). Aqui ele ainda não se identifica com os descendentes de Quitéria; todavia, lançada está a corda pela qual o texto o amarrará, na seqüência, àqueles descendentes: o modo de vingarem os sofrimentos dos ancestrais (enforcando os descendentes dos antigos senhores) é o mesmo que será empregado por Luís para eliminar Julião;

2- Luís reconhece-se (embora viva na civilização urbana e trabalhe no serviço público às voltas com a tarefa de escrever e fazer crítica literária - e não com os ofícios ligados à terra, como os de vaqueiro ou de agricultor) pertencente àquela raça descendente de Quitéria: "Estudava-me ao espelho, via, por entre as linhas dos anúncios, os beiços franzidos, os dentes acavalados, os olhos sem brilho, a testa enrugada, procurava os vestígios das duas raças infelizes. Foram elas que me tornaram a vida amarga e me fizeram rolar por este mundo, faminto, esmolambado e cheio de sonhos. Não preciso de automóveis nem de rádios, viveria bem numa casa de palha, dormia bem numa cama de varas, num couro de boi ou numa rede de cordas, como Quitéria, como o velho Trajano e Camilo Perira da Silva" (p. 131. Grifo nosso). Ainda neste segundo momento - o do reconhecimento de Luís com os descendentes de Quitéria e "das outras negras", magistralmente trabalhado por Graciliano ao pôr seu protagonista diante do espelho, o que significa perguntar-se "quem sou eu?" - lemos, no momento em que Luís segue Julião, este trecho confirmador dessa identificação : "A minha raiva crescia, raiva de cangaceiro emboscado. Por que esta comparação? Será que os cangaceiros experimentam a cólera que eu experimentava?" (p. 157);

3 - Luís, na emboscada, vê-se mais forte que Julião, posto tocaias recordarem-lhe o poderio do avô, "Nas redações, na repartição, no bonde, eu era um trouxa, um infeliz amarrado. Mas ali, na estrada deserta, voltar-me as costas como a um cachorro sem dentes! Não. Donde vinha aquela grandeza? Por que aquela segurança? Eu era um homem. Ali era um homem" (p. 159). Responde a pergunta, "Por que aquela segurança?", Luís mesmo, quando, linhas abaixo, exclama, " - José Baía, meu irmão...", e, irmanado com o antigo jagunço do avô, enforca Julião: "Retirei a corda do bolso e em alguns saltos, silenciosos como os das onças de José Baía, estava ao pé de Julião Tavares" (p. 159). Coloca-se assim na posição reconhecida pelo avô como sendo de prestígio (uma vez que Trajano tinha em boa conta seus cabras), o que vale dizer que Luís, adulto, continua buscando o reconhecimento do avô.

Além desse percurso de Luis Silva, ajudam a sustentar a tese anterior (a de que no assassinato de Julião Tavares encontra-se uma subversão da ordem social porque Luís Silva representa a civilização agrária e Julião a urbana) as conversas entre Luís e o comunista Moisés, este um pregador da revolução. Embora o texto não explicite que tenha sido por meio de Moisés que Luís politizou-se, fica a possibilidade de se tomar a execução de Julião como sendo a ação revolucionária de Luis, posto este, enquanto literato, não ser favorável a discursos e palavreados ocos; logo, não aderiu à propaganda política de Moisés: preferiu a ação à 
pregação; foi um homem da práxis e não do Logos.

Em sendo fundado nosso arrazoado, Angústia - distinto dos demais romances de 30 por razões que não comentaremos aqui - constituiria um caso à parte de Bangüê, Usina, Zefa entre os homens e A beata Maria do Egito, posto Graciliano nos fornecer um caso de execução política sem a intervenção do sobrenatural: de sobrenatural, só as reminiscências e os vultos do passado de Luís que vão Ihe dando, aos poucos, a forma de cangaceiro. Enformado assim, mata o burguês Julião Tavares. Catarse?

[xxii] Também _o conto_Tapera, do livro Sertão, Coelho Nettô, esquiva-se de narrar a alteração da ordem social. Andando pelo sertão, o narrador chega à tapera da fazenda Santa Luzia, com fama de assombrada - como outras que estamos vendo neste trabalho. Encontra-se lá com o antigo proprietário, decaído e com feições de mal-assombrado, o qual the narra sua historia de desgraças amorosas, ajudando a entender porque a fazenda (um engenho, como na ficção de José Lins) arruinou-se. O contato com o passado de Honório Silveira faz delirar e adoecer 0 narrador. No desfecho, os parentes advertem-no: "Foi visão que tiveste. Sonhaste, deliraste... Honório Silveira é morto, Leonor Silveira é morta, foram ambos victimas dos escravos revoltados. Todo o sertão conhece a historia do levante dos negros de Santa Luzia. Não há duendes nas terras nem viv'alma ali passa. Os sertanejos falam desse velho como falam do curupira e da yara das águas correntes. Foi visão que tiveste. Sonhaste, deliraste" (p. 119).

Por que não o conto da "história do levante dos negros de Santa Luzia" e sim o da visão? Parece haver uma espécie de interdito a impedir o escritor de subverter a sociedade instituída (por pertencer a ela?). De levante de escravos, até onde conhecemos, temos notícias apenas do de Mauro, do poema narrativo Mauro, o escravo, de Fagundes Varela, e do de Calupo, pai de Zonga, uma das matriarcas de As velhas, Adonias Filho. Castro Alves não nos dá nenhum, e mesmo o apaixonado e revoltado Lucas, de Cachoeira de Paulo Afonso, não executa vingança nenhuma, embora seus sofrimentos originem-se nas arbitrariedades dos brancos. Na virada para o séc. XX (o conto de Coelho Neto é do XIX, pois do livro Sertão há a crítica de Machado na crônica de 14/02/1897), escravos negros são substituídos pelos escravos brancos (trabalhadores e operários). Ao invés de levante de sertanejos, Zefa entre os homens, Usina e $A$ beta Maria do Egito colocam o braço de Deus levantando-se para castigar a soberba dos ricos, e não o braço dos próprios espoliados. Verdade é que, em Pedra Bonita, José Lins, aborda a organização dos sertanejos em torno de uma figura religiosa; todavia, não possui conotações políticas fortes no sentido de ser um levante. O lugar de Os Sertões, Euclides da Cunha, diante dessas questões não dá para ser debatido na exigüidade de uma nota apenas.

[xxiii] José Lins desenvolve aqui o tema presente em seu romance Pedra Bonita (1938): o fanatismo religioso das populações desassistidas pelo governo e pelos magnatas da terra

[xxiv] "A velha Nenen, um feixe de ossos, franzina, não acreditava na chaminé da Bom jesus, não ligava à riqueza que a esteira da usina trouxera" (p. 836). Evoca-nos o seu ceticismo o austero Frederico, senhor do engenho São Martinho de Olha para o céu, Frederico. Como Nenen, Frederico não se deixa levar pelo canto mavioso da sereia industrial. Prefere ficar com almanjarras e ser antes somítico que perdulário. Dessa forma, conduz lucrosamente os seus negócios, comprando dos parentes, entusiastas da modernidade, os títulos de dívida, resgatados depois com apropriação das terras. De igual modo. Fonseca, de $O$ coronel e 0 lobisomem, resiste às inovações de Ponciano (aumentar as aplicações, montar escritório. contratar funcionários, refinar o modo de vestir), não cedendo aos melhoramentos inventados 
[xxv] Impossível não mencionar agora Inseriro poema de "A educação pela pedra", Psicanálise do Açúcar: JCMN"O açúcar cristal, ou açúcar de usina, / mostra a mais instável das brancuras: / quem do Recife sabe direito o quanto, / e o pouco desse quanto, que ela dura. / Sabe o mínimo do pouco que o cristal / se estabiliza crista sobre o açúcar, / por cima do fundo antigo, de mascavo, / do mascavo barrento que se incuba; / e sabe que tudo pode romper o mínimo / em que o cristal é capaz de censura: / pois o tal fundo mascavo logo aflora / quer inverno ou verão mele o açúcar. // Só os banques que-ainda purgam ainda / o açúcar bruto com barro, de mistura: / a usina já não o purga: da infância, / não de depois de adulto, ela o educa; / em enfermarias. com vácuos e turbinas, / em maos de metal de gente indústria, / a usina o leva a sublimar em cristal / o pardo do xarope: não o purga, cura. / Mas como a cana se cria ainda hoje. / em mãos de barro de gente agricultura, / o barrento da pré-infância logo aflora / quer inverno ou verão mele o açúcar" (p. 356).

Mais que o "barrento da pré-infância", afloraram no cristal da Bom Jesus a barrenta água do Paraíba (como se a água esgoto retornasse aos "vácuos e turbinas" da usina) e o sangue dos inocentes do massacre do Alto da Areia.

[xxvi] Mesmas etapas observadas pelos usineiros da região de Campos, conforme o romance de José Candido Carvalho, Olha para o céu, Frederico: "Chegou no São Martinho no dobrar da tarde. Deu nome e profissão: Heinz Koster, representante de importante firma alemã. Vendia máquinas (...) Enfim, queria que eu visse as vantagens dos novos tipos de máquinas de usina. Koster louvava as moendas, os vácuos, as turbinas. Fez contas, cálculos. E acabou por dizer que a minha fábrica perdia, nos desperdícios das moendas, muitos contos de réis por safra. Conhecia bem o São Martinho. Era até bem aparelhado. Mas que esperava eu de uma ferragem velha e passada do tempo?" (p. 97)

[xxvii] O mesmo vale para a queda do café, tematizada em O rei da vela, Marco Zero le Marco Zero II, Oswald de Andrade, e A moratória, de Jorge Andrade.

[xxviii] Os santos do oratório de Feliciano, assuntos aos céus segundo a interpretação popular, na verdade foram afogados na lagoa, tendo antes o negro o cuidado de enfaixá-los. A enchente afoga a casa-grande da usina, assim como Feliciano teve que afogar os seus santos porque a ambição do usineiro expulsou-os de lá. Pena não ter o romancista noticiado o desfecho dos santos do oratório de D. Dondon: teriam sido levados na fuga e, portanto, feito o caminho da subida para a caatinga, ou teriam permanecido na casa-grande? nesse easto, sido afogados eomo os astigoE m qualquer um dos casos, repetir-se-ia_com os santos de $D$. Dondon 0 acontecido com os de Feliciano: êxodo para a caatinga ou afogamento. Todavia, não há referências disso no romance. Mas, dai a José Lins o que é de José Lins... 